\title{
Chemometric-Assisted Hydrophilic Interaction Chromatographic Method for the Determination of Gadolinium-Based Magnetic Resonance Imaging Contrast Agent in Liposomes
}

\author{
Ana Luiza C. Maia, ${ }^{a}$ Pedro Henrique R. da Silva, ${ }^{a}$ Christian Fernandes, ${ }^{a}$ Aline T. M. e Silva, ${ }^{a}$ \\ André Luís B. de Barros, ${ }^{b}$ Daniel Crístian F. Soares ${ }^{*, c}$ and Gilson A. Ramaldes ${ }^{a}$ \\ ${ }^{a}$ Departamento de Produtos Farmacêuticos, Faculdade de Farmácia, \\ Universidade Federal de Minas Gerais, 31270-901 Belo Horizonte-MG, Brazil \\ ${ }^{b}$ Departamento de Análises Clínicas e Toxicológicas, Faculdade de Farmácia, \\ Universidade Federal de Minas Gerais, 31270-901 Belo Horizonte-MG, Brazil \\ 'Laboratório de Bioengenharia, Universidade Federal de Itajubá, \\ Campus Itabira, 35903-087 Itabira-MG, Brazil
}

\begin{abstract}
Gadodiamide (Gd-DTPA-BMA) is a gadolinium (Gd) chelate composed of two carboxylate groups of diethylenetriaminepentaacetic acid (DTPA) and two amide groups (BMA). Gd complexes are the most widely used contrast agents in nuclear magnetic resonance. Furthermore, our research group has demonstrated the potential of liposomes containing Gd-DTPA-BMA for cancer therapy. The aim of this study was to develop and validate a chemometric-assisted method by hydrophilic interaction liquid chromatography (HILIC) for determination of Gd-DTPA-BMA in liposomes. The chromatographic conditions obtained were: Sequant ${ }^{\circledR}$ ZIC@-HILIC Merck $(150 \times 4.6 \mathrm{~mm}$, $3.5 \mu \mathrm{m}, 100 \AA$ ) column, mobile phase composed of $5 \mathrm{mmol} \mathrm{L}{ }^{-1} \mathrm{ACN} / \mathrm{NH}_{4} \mathrm{FA}, \mathrm{pH} 4.5(60: 40 \mathrm{v} / \mathrm{v})$ at $0.6 \mathrm{~mL} \mathrm{~min} \mathrm{~min}^{-1}$, injection volume of $20 \mu \mathrm{L}$, temperature of $30^{\circ} \mathrm{C}$, and detection at $210 \mathrm{~nm}$. The

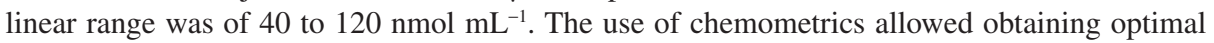
chromatographic parameters, in terms of signal-to-noise ratio, resolution, and asymmetry.
\end{abstract}

Keywords: gadodiamide, liposomes, hydrophilic interaction chromatography, chemometrics, Box-Behnken

\section{Introduction}

Gadodiamide (Gd-DTPA-BMA, Figure 1), a gadolinium (Gd) complex, is one of the most commonly used contrast agent in diagnosis by imaging, due to its low chemotoxicity. In addition, several studies have reported that there is no evidence of endogenous transmetalation or in vivo metabolism of this complex. Despite this, its administration is contraindicated in patients presenting chronic renal failure due to the risk of developing nephrogenic systemic fibrosis. ${ }^{1-3}$ Recently, the European Medicines Agency $(\mathrm{EMA})^{4}$ confirmed a review that found that Gd deposition can occur in brain tissues after the use of Gd contrast agents. Until the present date, there is no evidence that Gd deposition in the brain has caused any harm to patients. In order to prevent any risks that could potentially occur, $\mathrm{EMA}^{4}$ has

*e-mail: soares@unifei.edu.br recommended restrictions and suspensions for use of some intravenous linear agents containing Gd. Several studies have reported the encapsulation of Gd-DTPA-BMA and other Gd complexes in liposomes for diagnostic purposes..$^{5-7}$ The antitumor activity of this complex in the liposomal form is also being investigated, since Gd-DTPA-BMA induces the apoptosis of neoplastic cells through the activation of caspase-3., ${ }^{3,-12}$ In this context, thermosensitive liposomes constitute promising nanocarriers since they may contribute to increase the treatment efficacy due to the association with hyperthermia techniques. ${ }^{13}$

The determination of Gd-DTPA-BMA in environmental and biological samples has been performed most often by expensive techniques requiring complex instrumentation, such as inductively coupled plasma optical emission spectrometry and high performance liquid chromatography coupled to mass spectrometry (LC-MS). ${ }^{14-17}$ The Gd-DTPA-BMA quantification 


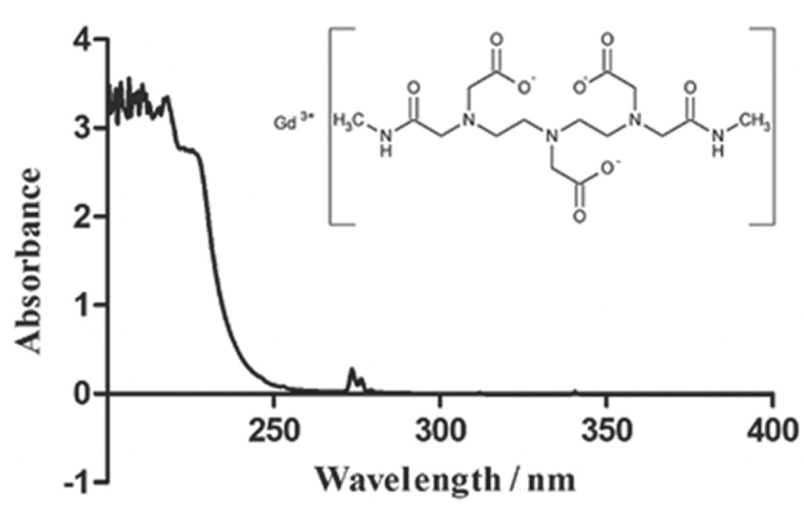

Figure 1. Structure and spectrum in the ultraviolet region of Gd-DTPA-BMA at $57 \mathrm{mg} \mathrm{mL}^{-1}$ in purified water.

method described in the United States Pharmacopeia ${ }^{18}$ employs LC with post-column derivatization to enable the detection of the complex in the region of the visible spectrum. However, derivatization generally requires special instrumentation and high reagent consumption. In addition, this additional step makes the analysis more time consuming. ${ }^{2}$ The determination of Gd-DTPA-BMA by LC using radioactivity detectors has also been described. ${ }^{17,19}$ In this case, the main disadvantage is related to the requirement of prior radiolabeling of the complex. In this context, the development of simpler, faster and low cost methods for determination of Gd-DTPA-BMA is extremely useful, mainly for determination of this complex in liposomal formulations. The development of liposomes can be laborious and consists of several stages. Thus, rapid information about the influence of changes in the formulation or in the preparation method on the amount of drug entrapment is required. Our group recently developed methods for quantification of Gd-DTPA-BMA by reverse phase liquid chromatography (RP-LC) and derivative spectrophotometry. In both methods, detection was performed in the ultraviolet region. ${ }^{2}$ The spectrophotometric method presented low detectability, while retention of Gd-DTPA-BMA in RP-LC was challenging due to its high polarity. Moreover, RP-LC method is not appropriate for determination of this drug in more complex matrices, such as serum, plasma, culture medium or buffers fortified with blood proteins. In these cases, RP-LC does not present adequate resolution. In addition, due to the impossibility to use any organic solvent in the mobile phase, optimization is limited.

Hydrophilic interaction liquid chromatography (HILIC) has been the technique of choice for the determination of polar compounds, especially metallic complexes. ${ }^{20}$ The increased use of HILIC may be related to its ability to resolve limitations of conventional chromatography. An example is the analysis of polar substances that present low retention in RP-LC. ${ }^{21}$ In HILIC, several chromatographic parameters can interfere in the retention and separation of the compounds. For this reason, the use of chemometric tools during the development of analytical methods is a useful approach. ${ }^{21,22}$ Recently, chemometrics have gained importance in the development of chromatographic methods, as can be observed in the scientific literature. ${ }^{23,24}$

Some methods for Gd-DTPA-BMA determination in biological and environmental samples by HILIC are described in the literature. ${ }^{20,25-29}$ However, none of these studies reported the determination of Gd-DTPA-BMA in liposomes, making necessary further investigations. Moreover, few data are presented in these studies concerning method optimization. In addition, to our knowledge, no studies have been reported on the development of method for determination of Gd-DTPA-BMA by HILIC, in which a rational approach has been used.

In this context, the aim of this study was to develop and validate an analytical method for the determination of Gd-DTPA-BMA in liposomes by HILIC. For this, Box-Behnken factorial planning and response surface methodology were used during the method development. The method was validated according to the Brazilian legislation ${ }^{30}$ and the $\mathrm{ICH}$ validation guidelines for analytical procedures $\mathrm{Q} 2(\mathrm{R} 1)^{31}$ and applied for determination of Gd-DTPA-BMA entrapment in liposomes.

\section{Experimental}

Materials

Gd-DTPA-BMA (Omniscan®, General Electric Healthcare Company, Ireland) was purchased from HDL Logística Hospitalar (Uberlândia, Brazil), batch 12,747,449, content of $99.7 \%$. Dipalmitoylphosphatidylcholine (DPPC), distearoylphosphatidylcholine (DSPC), and distearoylphosphatidylethanolamine-polyethyleneglycol ${ }_{2000}$ $\left(\mathrm{DSP}-\mathrm{PEG}_{2000}\right.$ ) were purchased from Lipoid $\mathrm{GmbH}$ (Ludwigshafen, Germany). Monostearoylphosphatidylcholine (MSPC) was purchased from Avanti Lipids (Alabama, USA). HEPES (4-(2-hydroxyethyl)1-piperazine-ethanesulfonic acid) was purchased from Sigma Chemical Company (St. Louis, USA). Acetonitrile (ACN) HPLC grade was purchased from Tedia Brazil (Rio de Janeiro, Brazil) and from J.T.Baker (Pennsylvania, USA). Hydrochloric acid and chloroform were purchased from LabSynth (São Paulo, Brazil). Diethyl ether, and isopropyl alcohol HPLC grade were purchased from Vetec (Rio de Janeiro, Brazil). The water used to prepare all the solutions and samples was purified on a Milli-Q® Direct-Q3 Millipore system (Billerica, USA). Ammonium 
acetate $\left(\mathrm{NH}_{4} \mathrm{Ac}\right)$ was purchased from Neon (São Paulo, Brazil). Ammonium formate $\left(\mathrm{NH}_{4} \mathrm{FA}\right)$ was purchased from Spectrum (São Paulo, Brazil) and from Vetec (Rio de Janeiro, Brazil).

\section{Chromatographic conditions}

HILIC was performed using a 1260 series chromatograph (Agilent Technologies, California, USA), equipped with a degasser, a quaternary pump (G1311B), a column oven (G1316A), an autosampler (G1329B), and a diode array detector (DAD) (G4212B), coupled to the EzChrom integration program. The chromatographic conditions of the developed method were: Sequant ${ }^{\circledR}$ ZIC $®$-HILIC Merck $(150 \times 4.6 \mathrm{~mm}, 3.5 \mu \mathrm{m}, 100 \AA)$ column (Darmstadt, Germany), mobile phase composed of $5 \mathrm{mmol} \mathrm{L}{ }^{-1} \mathrm{ACN} / \mathrm{NH}_{4} \mathrm{FA}$, $\mathrm{pH} 4.5(60: 40 \mathrm{v} / \mathrm{v})$ isocratically eluted at a flow-rate of $0.6 \mathrm{~mL} \mathrm{~min}{ }^{-1}$, injection volume of $20 \mu \mathrm{L}$, temperature of $30^{\circ} \mathrm{C}$, and detection at $210 \mathrm{~nm}$.

\section{Preparation of liposomes}

Thermosensitive formulations containing Gd-DTPA-BMA were prepared by reverse-phase evaporation method using the procedure described in a previous study by our research group. ${ }^{3,32}$ The total lipid concentration for the two liposomes was $40 \mathrm{mmol} \mathrm{L}^{-1}$. The composition of each formulation was chosen based on the studies of $\mathrm{Li} e a l^{33}$ For the preparation of the traditional thermosensitive liposome (TTSL-Gd), chloroform aliquots of DPPC, DSPC, and DSPE-PEG 2000 , in a lipid molar ratio of 80:15:5, were transferred to a round-bottomed flask and subjected to solvent evaporation under reduced pressure. The thermosensitive liposome containing lysophospholipid (LTSL-Gd) was prepared from chloroform aliquots of DPPC, MSPC, and DSPE-PEG 2000 , in lipid molar ratio of 85:10:5. The lipid film obtained in both cases was dissolved in diethyl ether, previously treated with a solution of $10 \mathrm{mmol} \mathrm{L}^{-1}$ HEPES buffer. After complete dissolution of the lipids, an aqueous solution of Gd-DTPA-BMA $\left(250 \mu \mathrm{mol} \mathrm{mL} \mathrm{mL}^{-1}\right)$ was added, maintaining the aqueous:organic phase ratio at 1:3. Then, the dispersion obtained was subjected to vigorous vortexing at 3,000 rpm for $5 \mathrm{~min}$, producing a water in oil (W/O) emulsion. Subsequently, the W/O emulsion was subjected to evaporation under reduced pressure to remove the organic solvent, enabling the formation of lipid vesicles. Then, the obtained liposomes were calibrated employing 10 cycles of extrusion on polycarbonate membranes of $0.4,0.2$, and $0.1 \mu \mathrm{m}$ pore sizes, under nitrogen pressure, at $55^{\circ} \mathrm{C}$. Non-entrapped Gd-DTPA-BMA was separated from liposomes by ultracentrifugation at $350,000 \times \mathrm{g}$, at $4{ }^{\circ} \mathrm{C}$ for
$2 \mathrm{~h}$. After ultracentrifugation, the pellet was reconstituted in HEPES buffer to obtain the same initial volume. To obtain the traditional thermosensitive liposomes (TTSL) and thermosensitive liposome containing lysophospholipid (LTSL) without Gd-DTPA-BMA, the same experimental protocol was performed, except for the step of addition of the drug, which was replaced by the addition of HEPES buffer.

\section{HILIC method development}

Initially, a review of the literature was carried out to determine the critical independent variables for the development of methods for determination of Gd-DTPA-BMA by HILIC. To determine the detection wavelength, the UV spectrum in the range of 200 to $400 \mathrm{~nm}$ of a Gd-DTPA-BMA sample at $57 \mathrm{mg} \mathrm{mL}^{-1}$ was obtained. The analyses were performed using a Shimadzu 1800 series UV-Vis spectrophotometer (Tokyo, Japan). Then, 11 experiments were performed as described in Table 1 to investigate the range of variation and levels at which independent variables should be evaluated in a factorial design. In each experiment, nine determinations were performed, being three determinations on a sample

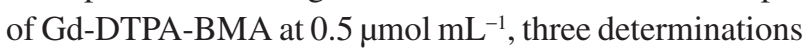
on a sample of TTSL spiked with Gd-DTPA-BMA at

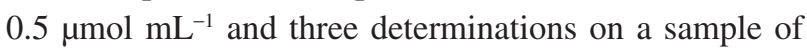
LTSL spiked with Gd-DTPA-BMA at $0.5 \mu \mathrm{mol} \mathrm{mL} \mathrm{m}^{-1}$.

The optimization of the chromatographic parameters was performed using Box-Behnken factorial design and response surface methodology. ${ }^{34}$ Three independent variables at three levels $(-1,0$ and 1$)$ were evaluated: $\mathrm{X}_{1}=$ buffer $\mathrm{pH}$, level $-1=3.7$, level $0=4.2$ and level $+1=4.7 ; X_{2}=$ ACN ratio in the mobile phase (in percentage), level $-1=60$, level $0=65$, level $+1=70$; $\mathrm{X}_{3}=$ buffer concentration $\left(\mathrm{mmol} \mathrm{L}^{-1}\right)$, level $-1=5$, level $0=15$, level $+1=25$. The dependent variables evaluated as responses were: signal-to-noise ratio, resolution $\left(\mathrm{R}_{\mathrm{s}}\right)$, and asymmetry $\left(A_{s}\right)$. Fifteen experiments were performed in random order, including three replicates of the central point. Six determinations were performed in each experiment, being three determinations on a sample of Gd-DTPA-BMA at $0.3 \mu \mathrm{mol} \mathrm{mL} \mathrm{mL}^{-1}$ and three determinations on a sample of TTSL and LTSL spiked with Gd-DTPA-BMA at $0.3 \mu \mathrm{mol} \mathrm{mL} \mathrm{m}^{-1}$. The coefficients of determination $\left(\mathrm{r}^{2}\right)$ and correlation (r) were obtained using the least squares method. The model was evaluated using analysis of variance (ANOVA) and the estimation of the errors was calculated by means of experiments at the central point. The results were evaluated using the software Statistica 7.0. ${ }^{35}$

In order to determine the linear velocity in which the height equivalent to a theoretical plate $(\mathrm{H})$ is minimal, a Van 
Table 1. Variables screening for development of method for determination of Gd-DTPA-BMA in liposomes by HILIC

\begin{tabular}{|c|c|c|c|}
\hline Experiment & Parameter evaluated & Independent variable & Mobile phase composition \\
\hline 1 & \multirow{2}{*}{ type of buffer } & $\mathrm{NH}_{4} \mathrm{Ac}$ & $\mathrm{ACN} / \mathrm{NH}_{4} \mathrm{Ac} 10 \mathrm{mmol} \mathrm{L}{ }^{-1}, \mathrm{pH} 5.8,70: 30 \mathrm{v} / \mathrm{v}$ \\
\hline 2 & & $\mathrm{NH}_{4} \mathrm{FA}$ & $\mathrm{ACN} / \mathrm{NH}_{4} \mathrm{FA} 10 \mathrm{mmol} \mathrm{L}^{-1}, \mathrm{pH} 4.7,70: 30 \mathrm{v} / \mathrm{v}$ \\
\hline 3 & \multirow{3}{*}{$\mathrm{ACN}$ ratio } & $60 \%$ & $\mathrm{ACN} / \mathrm{NH}_{4} \mathrm{FA} 10 \mathrm{mmol} \mathrm{L}^{-1}, \mathrm{pH} 4.7,60: 40 \mathrm{v} / \mathrm{v}$ \\
\hline 4 & & $70 \%$ & $\mathrm{ACN} / \mathrm{NH}_{4} \mathrm{FA} 10 \mathrm{mmol} \mathrm{L}^{-1}, \mathrm{pH} 4.7,70: 30 \mathrm{v} / \mathrm{v}$ \\
\hline$\underline{5}$ & & $75 \%$ & $\mathrm{ACN} / \mathrm{NH}_{4} \mathrm{FA} 10 \mathrm{mmol} \mathrm{L}^{-1}, \mathrm{pH} 4.7,75: 25 \mathrm{v} / \mathrm{v}$ \\
\hline 6 & \multirow{3}{*}{ buffer concentration } & $5 \mathrm{mmol} \mathrm{L}^{-1}$ & $\mathrm{ACN} / \mathrm{NH}_{4} \mathrm{FA} 5 \mathrm{mmol} \mathrm{L}^{-1}, \mathrm{pH} 4.7,70: 30 \mathrm{v} / \mathrm{v}$ \\
\hline 7 & & $10 \mathrm{mmol} \mathrm{L}^{-1}$ & $\mathrm{ACN} / \mathrm{NH}_{4} \mathrm{FA} 10 \mathrm{mmol} \mathrm{L}-1, \mathrm{pH} 4.7,70: 30 \mathrm{v} / \mathrm{v}$ \\
\hline 8 & & $15 \mathrm{mmol} \mathrm{L}^{-1}$ & $\mathrm{ACN} / \mathrm{NH}_{4} \mathrm{FA} 15 \mathrm{mmol} \mathrm{L}-1, \mathrm{pH} 4.7,70: 30 \mathrm{v} / \mathrm{v}$ \\
\hline 9 & \multirow{3}{*}{ the aqueous phase $\mathrm{pH}$ of the mobile phase } & 2.7 & $\mathrm{ACN} / \mathrm{NH}_{4} \mathrm{FA} 10 \mathrm{mmol} \mathrm{L}^{-1}, \mathrm{pH} 2.7,70: 30 \mathrm{v} / \mathrm{v}$ \\
\hline 10 & & 3.7 & $\mathrm{ACN} / \mathrm{NH}_{4} \mathrm{FA} 10 \mathrm{mmol} \mathrm{L}^{-1}, \mathrm{pH} 3.7,70: 30 \mathrm{v} / \mathrm{v}$ \\
\hline 11 & & 4.7 & $\mathrm{ACN} / \mathrm{NH}_{4} \mathrm{FA} 10 \mathrm{mmol} \mathrm{L}^{-1}, \mathrm{pH} 4.7,70: 30 \mathrm{v} / \mathrm{v}$ \\
\hline
\end{tabular}

Deemter curve was constructed. ${ }^{36}$ For this, mobile phase flow-rate was varied as follows: $0.04 ; 0.06 ; 0.08 ; 0.1 ; 0.2$; $0.3 ; 0.4 ; 0.5 ; 0.6 ; 0.7 ; 0.8 ; 0.9 ; 1.0 ; 1.5$ and $2.0 \mathrm{~mL} \mathrm{~min}^{-1}$. For each flow-rate its correspondent number of theoretical plates $(\mathrm{N})$ and retention time $\left(\mathrm{t}_{\mathrm{R}}\right)$ were obtained. The curve was obtained by plotting the $\mathrm{H}$ as a function of the linear velocity of the mobile phase $\left(\mathrm{U}_{0}\right)$.

\section{Method validation}

Selectivity was demonstrated by the separation of Gd-DTPA-BMA from all potentially interfering compounds, with adequate resolution. Gd-DTPA-BMA chromatograms in the lower concentration of analytical curve $(40 \mathrm{nmol} \mathrm{mL}-1)$ and those from mobile phase, isopropyl alcohol, TTSL/LTSL, and fetal bovine serum were overlapped to demonstrate the absence of interfering peaks in the same $t_{R}$ of Gd-DTPA-BMA. The fetal bovine serum was previously ultrafiltered in a centrifugal filter device (Amicon® ${ }^{\circledR}$ Ultra-4 $10 \mathrm{kDa}$ MWCO, Millipore, Billerica, USA) by centrifugation at $14,000 \times \mathrm{g}$ for $20 \mathrm{~min}$. All samples were prepared using mobile phase as solvent. The liposomes were previously solubilized in isopropyl alcohol at the ratio of 1:10 for complete disruption of the vesicles. Peak purity was also evaluated. ${ }^{30,31}$

Five concentration levels were used, in triplicate, to determine linearity. The linear range evaluated was 50 to $150 \%$ of the working concentration $\left(80 \mathrm{nmol} \mathrm{mL}^{-1}\right)$, which corresponds to the concentrations of $40,60,80,100$, and

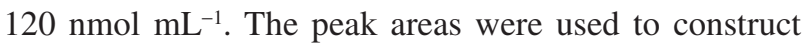
the analytical curve. Linear regression was verified by the least squares method using GraphPad Prism 5.0 software program. ${ }^{37}$ The coefficients $r$ and $r^{2}$ were evaluated.

The limits of detection (LOD) and quantification (LOQ) were initially determined by evaluating the signal- to-noise ratio. For this, Gd-DTPA-BMA solutions were prepared, using mobile phase as solvent, in decreasing concentrations in the range of 50 to $0.05 \mathrm{nmol} \mathrm{mL}^{-1}$. LOD and LOQ were defined as the concentrations for which signal-to-noise ratios of 3:1 and 10:1, respectively, were obtained. After determination of linearity, LOD and LOQ were also calculated based on the standard deviation (SD) of the $y$-intercept when $x=0$ and the slope of the calibration curve of Gd-DTPA-BMA. ${ }^{38}$

Intra-day precision was evaluated by means of nine determinations, being three concentrations (50,100 and $150 \%$ of the working concentration) in triplicate, corresponding to the concentrations of 40,80 and $120 \mathrm{nmol} \mathrm{mL}^{-1}$. To determine inter-days precision, the same procedure was performed on alternate days. The relative standard deviation (RSD) of the determinations was calculated.

The accuracy was determined by quantification of Gd-DTPA-BMA in the presence of the components of the formulations. TTSL and LTSL, without the drug, were spiked with Gd-DTPA-BMA at 40, 80 and $120 \mathrm{nmol} \mathrm{mL}^{-1}$. Samples were prepared in triplicate and the results were expressed as percentage recovery of the drug added to the placebo.

The robustness was evaluated by means of the Youden test by deliberately modifying seven conditions of the chromatographic method: ACN ratio in the mobile phase, mobile phase aqueous component $\mathrm{pH}$, buffer concentration, column temperature, flow-rate, ACN brand, and buffer brand. ${ }^{39}$ The levels of the modified variables as well as the factorial combination of the experimental planning are described in Table 2. The seven parameters and their respective modifications were combined in eight experiments that were performed in random order. Six determinations were performed in each condition, being three determinations on a sample of Gd-DTPA-BMA

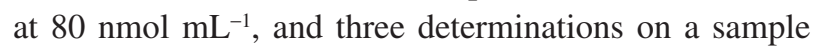


Table 2. Experimental planning for robustness assessment by means of Youden test

\begin{tabular}{|c|c|c|c|c|c|c|c|c|c|c|}
\hline \multirow{2}{*}{ Analytical parameter } & \multicolumn{2}{|c|}{ Condition } & \multicolumn{8}{|c|}{ Factorial combination } \\
\hline & Nominal & Varied & 1 & 2 & 3 & 4 & 5 & 6 & 7 & 8 \\
\hline $\mathrm{ACN}$ ratio in the mobile phase $/ \%$ & $60(\mathrm{~A})$ & 63 (a) & A & A & A & A & $\mathrm{a}$ & $\mathrm{a}$ & a & a \\
\hline The aqueous phase $\mathrm{pH}$ of the mobile phase & $4.5(\mathrm{~B})$ & 4.7 (b) & B & B & $\mathrm{b}$ & $\mathrm{b}$ & B & B & $\mathrm{b}$ & $\mathrm{b}$ \\
\hline Buffer concentration / $\left(\mathrm{mmol} \mathrm{L}^{-1}\right)$ & $5(\mathrm{C})$ & $5.5(\mathrm{c})$ & $\mathrm{C}$ & $\mathrm{c}$ & $\mathrm{C}$ & $\mathrm{c}$ & $\mathrm{C}$ & $\mathrm{c}$ & $\mathrm{C}$ & $\mathrm{c}$ \\
\hline Column temperature $/{ }^{\circ} \mathrm{C}$ & 30 (D) & $33(d)$ & $\mathrm{D}$ & $\mathrm{D}$ & $\mathrm{d}$ & $\mathrm{d}$ & $\mathrm{d}$ & $\mathrm{d}$ & $\mathrm{D}$ & $\mathrm{D}$ \\
\hline Flow-rate $/\left(\mathrm{mL} \mathrm{min}^{-1}\right)$ & $0.6(\mathrm{E})$ & 0.7 (e) & $\mathrm{E}$ & $\mathrm{e}$ & $\mathrm{E}$ & $\mathrm{e}$ & e & $\mathrm{E}$ & $\mathrm{e}$ & $\mathrm{E}$ \\
\hline ACN brand & Tedia (F) & J.T. Baker (f) & $\mathrm{F}$ & $\mathrm{f}$ & $\mathrm{f}$ & $\mathrm{F}$ & $\mathrm{F}$ & $\mathrm{f}$ & $\mathrm{f}$ & $\mathrm{F}$ \\
\hline Buffer brand & $\operatorname{Vetec}(\mathrm{G})$ & Spectrum (g) & $\mathrm{G}$ & $\mathrm{g}$ & $\mathrm{g}$ & G & $\mathrm{g}$ & G & G & $\mathrm{g}$ \\
\hline
\end{tabular}

of TTSL and LTSL spiked with Gd-DTPA-BMA at $80 \mathrm{nmol} \mathrm{mL} \mathrm{m}^{-1}$.

\section{Results and Discussion}

\section{HILIC method development}

In general, the stationary phase and the mobile phase are the most important factors for the development of analytical methods by HILIC. ${ }^{21,22}$ In the present study, a SeQuant ${ }^{\circledR}$ ZIC®-HILIC $(150 \times 4.6 \mathrm{~mm}, 3.5 \mu \mathrm{m}, 100 \AA)$ column was used. This column was chosen based on the chemical structure and some physical-chemical properties of Gd-DTPA-BMA. ZIC®-HILIC, which contains a sulfobetaine binder, is indicated for the analysis of ionic and non-ionic polar compounds. ${ }^{21,40}$ Gd-DTPA-BMA is a non-ionic complex, relatively stable due to its $\log \mathrm{Ks}$ (logarithm of the complex stability constant) value equal to $16.85 .^{1}$ The absence of charges in the complex suggests that the hydrophilic partition is probably the main retention mechanism. The sulfobetaine binder adsorbs a large amount of water on the surface of the stationary phase through hydrogen bonding. ${ }^{22,40}$ Thus, Gd-DTPA-BMA will possibly exhibit higher affinity for the stationary phase compared to affinity for the solvent-rich mobile phase. Gd-DTPA-BMA is freely soluble in water and has a log P (logarithm of octanol / water partition coefficient) of $-2.13 .^{41,42}$ These characteristics support the hypothesis of the hydrophilic partition retention mechanism.

A typical mobile phase employed in HILIC is composed of an organic portion (water miscible polar solvent) in a ratio equal to or higher than $60 \%$ and an aqueous portion containing or not some type of buffer in a ratio equal to or higher than $2 \% .^{21,43} \mathrm{ACN}$ and methanol are the most commonly used organic solvents in HILIC. In the present study, ACN was selected since the use of a protic solvent, such as methanol, could drastically reduce the retention of Gd-DTPA-BMA. In this case, the use of a higher amount of solvent would be necessary to obtain the same retention provided by an aprotic solvent. ${ }^{22,44}$ Buffers are employed in HILIC if the control of the mobile phase $\mathrm{pH}$ is required and when peak asymmetry can be a problem. ${ }^{22}$ Commonly, the determination of Gd-DTPA-BMA by RP-LC reveals tailing peaks and high value of $\mathrm{As}_{\mathrm{s}} \cdot{ }^{17,45,46}$ Therefore, $\mathrm{pH}$ control of the mobile phase using buffers was used in the proposed method. The buffers usually used in HILIC are $\mathrm{NH}_{4} \mathrm{Ac}$ and $\mathrm{NH}_{4} \mathrm{FA}$, due to the high solubility in organic solvents, even in high concentrations, and due to the volatility they present, being compatible with MS detectors. ${ }^{21}$ Although they exhibit similar characteristics, the use of $\mathrm{NH}_{4} \mathrm{Ac}$ or $\mathrm{NH}_{4} \mathrm{FA}$ may result in different elution profiles. ${ }^{47,48}$ For this reason, both buffers were investigated at this initial screening.

To determine the detection wavelength, the UV spectrum in the range of 200 to $400 \mathrm{~nm}$ of a Gd-DTPA-BMA sample at $57 \mathrm{mg} \mathrm{mL}^{-1}$ was obtained. Due to the lack of extended chromophores in its structure, Gd-DTPA-BMA showed maximum absorption at $210 \mathrm{~nm}$ (Figure 1).

After choosing the stationary phase type (ZIC®-HILIC), the organic solvent $(\mathrm{ACN})$, the possible buffers $\left(\mathrm{NH}_{4} \mathrm{Ac}\right.$ and $\left.\mathrm{NH}_{4} \mathrm{FA}\right)$, the detection wavelength $(210 \mathrm{~nm})$, the temperature $\left(30^{\circ} \mathrm{C}\right)$, and the injection volume $(20 \mu \mathrm{L})$, 11 experiments were carried out, in order to define the variables and range of variation to be evaluated in a later factorial design. The results of this step are showed in Table S1 (Supplementary Information (SI) section).

The use of $\mathrm{NH}_{4} \mathrm{FA}(\mathrm{pH}=4.7)$ resulted in a signal-tonoise ratio about three times higher than that obtained with $\mathrm{NH}_{4} \mathrm{Ac}(\mathrm{pH}=5.8)$, leading to higher detectability. A higher value of $\mathrm{N}$ is another advantage observed with the use of $\mathrm{NH}_{4} \mathrm{FA}$. The $\mathrm{R}_{\mathrm{s}}$ between Gd-DTPA-BMA and liposomes peaks, obtained with $\mathrm{NH}_{4} \mathrm{FA}\left(\mathrm{R}_{\mathrm{s}}=6.9\right)$, under the conditions evaluated, was lower than that obtained with $\mathrm{NH}_{4} \mathrm{Ac}\left(\mathrm{R}_{\mathrm{s}}=11.8\right)$; however, it was adequate $\left(\mathrm{R}_{\mathrm{s}} \geq 2\right)$ according to the validation guides. ${ }^{49-51}$ For these reasons, $\mathrm{NH}_{4} \mathrm{FA}$ buffer was selected to compose the mobile phase and to be used in the following experiments. 
The range selected for evaluation of the percentage of ACN, based on the results of Table S1 (SI section), was between 60 and $70 \%$. The minimum level of $60 \%$ was selected because in this condition $t_{R}$ was appropriate $\left(t_{R}=4.3 \mathrm{~min}\right)$ and the value of retention factor $(\mathrm{k})$ obtained $(\mathrm{k}=1.7)$ is within the recommended range $0.5<\mathrm{k}<20 .{ }^{51}$ The maximum level of $70 \%$ was also chosen based on $t_{R}$ and $k$ values obtained $\left(t_{R}=8.6 \min , k=4.4\right)$. Ratios of ACN above $70 \%$ were not considered, since the $t_{R}$ of Gd-DTPA-BMA becomes very long.

The concentration of $\mathrm{NH}_{4} \mathrm{FA}$ buffer was evaluated in the experiments 6,7 , and 8 (Table 1). The range of variation chosen for evaluation in a factorial design was between 5 and $25 \mathrm{mmol} \mathrm{L}^{-1}$. The minimum level of $5 \mathrm{mmol} \mathrm{L}^{-1}$ was selected because it is the minimum concentration necessary to obtain symmetrical peaks. ${ }^{21}$ The maximum level of $25 \mathrm{mmol} \mathrm{L}^{-1}$, although not tested experimentally, was selected because it is described in the literature as the limit concentration in which there is no probability of precipitation in contact with ACN. ${ }^{52}$

Experiments 9, 10, and 11 were performed to evaluate the mobile phase aqueous component $\mathrm{pH}$ (Table 1). The entire $\mathrm{NH}_{4} \mathrm{FA}$ buffering range was investigated. Based on the results (Table $\mathrm{S} 1$, SI section), $\mathrm{pH}$ values between 3.7 and 4.7 were chosen for evaluation in a factorial design. The minimum level of 3.7 was selected, since it corresponded to the lowest $\mathrm{pH}$ value in which Gd-DTPA-BMA remained stable. When using $\mathrm{pH} 2.7$, it was not possible to calculate most of the dependent variables expressed in Table S1 (SI section), due to the deformation of the chromatographic peak corresponding to the drug. The maximum level of 4.7 was selected because, in this condition, satisfactory results were obtained. In addition, this value corresponds to the maximum $\mathrm{pH}$ of the $\mathrm{NH}_{4} \mathrm{FA}$ buffering range.

The variables chosen to compose the factorial planning, based on the initial screening, were: mobile phase aqueous component $\mathrm{pH}\left(\mathrm{X}_{1}\right), \mathrm{ACN}$ ratio $\left(\mathrm{X}_{2}\right)$, and buffer concentration $\left(\mathrm{X}_{3}\right)$. The other chromatographic conditions were fixed: SeQuant ${ }^{\circledR}$ ZIC $®$-HILIC $(150 \times 4.6 \mathrm{~mm}$, $3.5 \mu \mathrm{m}, 100 \AA$ ) column, isocratic elution at $1.0 \mathrm{~mL} \mathrm{~min}^{-1}$, injection volume of $20 \mu \mathrm{L}$, temperature of $30{ }^{\circ} \mathrm{C}$, and detection at $210 \mathrm{~nm}$. The responses chosen to evaluate the efficiency of the method were: signal-to-noise ratio, $R_{s}$, and $\mathrm{A}_{\mathrm{s}}$. These dependent variables were selected based on the application of the proposed method. The experimental conditions evaluated, and the responses obtained are presented in Table 3.

The obtained signal-to-noise ratios showed high variation between the experiments (minimum 1645031 and maximum 9622069). With respect to $R_{s}$, experiments 3 ,

Table 3. Results from Box-Behnken experimental design used for optimization of the HILIC method

\begin{tabular}{|c|c|c|c|c|c|c|c|c|c|}
\hline & \multirow{2}{*}{\multicolumn{4}{|c|}{ Independent variable }} & \multicolumn{5}{|c|}{ Level } \\
\hline & & & & & \multicolumn{2}{|c|}{-1} & 0 & \multicolumn{2}{|c|}{1} \\
\hline $\mathrm{X}_{1}$ & \multicolumn{4}{|c|}{$\mathrm{pH}$} & \multicolumn{2}{|c|}{3.7} & 4.2 & \multicolumn{2}{|c|}{4.7} \\
\hline $\mathrm{X}_{2}$ & \multicolumn{4}{|c|}{$\mathrm{ACN}$ ratio $/ \%$} & \multicolumn{2}{|c|}{60} & 65 & \multicolumn{2}{|c|}{70} \\
\hline $\mathrm{X}_{3}$ & \multicolumn{4}{|c|}{ buffer concentration / $\left(\mathrm{mmol} \mathrm{L}^{-1}\right)$} & \multicolumn{2}{|c|}{5} & 15 & \multicolumn{2}{|c|}{25} \\
\hline \multirow{2}{*}{ Experiment } & \multicolumn{3}{|c|}{ Contrast } & \multicolumn{3}{|c|}{ Experimental condition } & \multicolumn{3}{|c|}{ Dependent variable $^{\mathrm{a}}$} \\
\hline & $\mathrm{X}_{1}$ & $\mathrm{X}_{2}$ & $\mathrm{X}_{3}$ & $\mathrm{X}_{1}$ & $\mathrm{X}_{2}$ & $\mathrm{X}_{3}$ & Signal-to-noise ratio & $\mathrm{R}_{\mathrm{s}}$ & $\mathrm{A}_{\mathrm{s}}$ \\
\hline 1 & 1 & 1 & 0 & 4.7 & 70 & 15 & 7164899 & 7.7 & 1.32 \\
\hline 2 & 1 & -1 & 0 & 4.7 & 60 & 15 & 7846412 & 3.7 & 1.18 \\
\hline 3 & -1 & 1 & 0 & 3.7 & 70 & 15 & 4029493 & 1.3 & 1.31 \\
\hline 4 & -1 & -1 & 0 & 3.7 & 60 & 15 & 6040335 & 0.0 & 1.21 \\
\hline 5 & 1 & 0 & 1 & 4.7 & 65 & 25 & 1675031 & 5.1 & 1.31 \\
\hline 6 & 1 & 0 & -1 & 4.7 & 65 & 5 & 9622069 & 5.5 & 1.25 \\
\hline 7 & -1 & 0 & 1 & 3.7 & 65 & 25 & 6731611 & 0.0 & 1.27 \\
\hline 8 & -1 & 0 & -1 & 3.7 & 65 & 5 & 7473207 & 4.0 & 1.25 \\
\hline 9 & 0 & 1 & 1 & 4.2 & 70 & 25 & 2324785 & 7.2 & 1.30 \\
\hline 10 & 0 & 1 & -1 & 4.2 & 70 & 5 & 5124660 & 7.2 & 1.33 \\
\hline 11 & 0 & -1 & 1 & 4.2 & 60 & 25 & 3487648 & 2.7 & 1.23 \\
\hline 12 & 0 & -1 & -1 & 4.2 & 60 & 5 & 6514122 & 3.5 & 1.19 \\
\hline $13^{\mathrm{b}, \mathrm{c}}$ & 0 & 0 & 0 & 4.2 & 65 & 15 & 2293381 & 3.7 & 1.27 \\
\hline
\end{tabular}

${ }^{a}$ Values are expressed as mean of 3 injections; ${ }^{b}$ values are expressed as mean $\left(n=3\right.$ samples, being 3 injections for each sample); ${ }^{c}$ central point. $R_{s}$ : resolution; $\mathrm{A}_{\mathrm{s}}$ : asymmetry. 
4 , and 7 (Table 3) generated results lower than the recommended value, which should be $\geq 2 .{ }^{49-51}$ These data suggest that the combination of low $\mathrm{pH}$ (3.7) and intermediate $\left(15 \mathrm{mmol} \mathrm{L}^{-1}\right)$ or high $\left(25 \mathrm{mmol} \mathrm{L}^{-1}\right)$ buffer concentration in the mobile phase composition should be avoided, as they may result in inadequate $R_{s}$ between the Gd-DTPA-BMA peak and the liposome peak. In terms of $A_{s}$, the observed results presented low variation (minimum 1.18 and maximum 1.33).

In order to extrapolate the data obtained by the Box-Behnken matrix and calculate the optimal point for the variables $X_{1}, X_{2}$ and $X_{3}$, the data presented in Table 3 were used to construct mathematical models. By combining the values of the variables and the responses obtained, the coefficients of the equations which describe the studied system were calculated (Table S2, SI section). These equations were elaborated from the effects of the primary linear and quadratic interactions. Secondary interactions were excluded because they generated experimentally incoherent optimal points. The ANOVA, $r, r^{2}$ and pure error data calculated from the central point replicates are described in Table S2 (SI section). The value of $\mathrm{r}^{2}$ obtained (close to 1) was satisfactory. ${ }^{53}$ In addition, the residuals showed random behavior, without tendencies, confirming the fit of the calculated model (Figure S1, SI section). The response surfaces obtained are shown in Figures 2, 3 , and 4 . The independent variables were grouped two by two to evaluate the influence of the interaction between them, in the responses signal-to-noise ratio, $R_{s}$, and $A_{s}$. In the Figures 2, 3, and 4, the graphs a-c were obtained employing constant buffer concentration. In the graphs d-f the fixed parameter was the ACN ratio. The g-i graphs were prepared by maintaining the values of the mobile phase aqueous component $\mathrm{pH}$ constant. The fixed value of each of these variables is indicated in parentheses above the respective graph.

For signal-to-noise ratio evaluation, shown in Figure 2, it can be seen from the scale of the graphs $2 a-2 c$ that the lower the concentration of the buffer, the higher the response. According to graph $2 \mathrm{a}$, higher values of signalto-noise ratio are obtained when using $\mathrm{pH} \geq 4$.4, regardless of the ACN ratio used. The results showed in the graphs $2 \mathrm{~d}-2 \mathrm{f}$ are in agreement with these observations. The values of the scales of the graphs $2 \mathrm{~g}-2 \mathrm{i}$, demonstrate that the highest responses are obtained when the highest $\mathrm{pH}$ of the buffering range of $\mathrm{NH}_{4} \mathrm{FA}$ was used (graph 2i). According to graph $2 \mathrm{i}$, regardless of the ACN ratio, the highest signalto-noise ratio was observed when the buffer concentration was $10 \mathrm{mmol} \mathrm{L}^{-1}$ or less. From the analysis of the nine response surfaces presented in Figure 2, mobile phase aqueous component $\mathrm{pH}$ (values ranging from 4.4 to 4.7 ) and the buffer concentration $\left(\leq 10 \mathrm{mmol} \mathrm{L}^{-1}\right)$ are the factors that most influence the signal-to-noise ratio.

The results of $R_{s}$ are presented in Figure 3. According to graphs 3a-3c, when the lowest concentration of buffer was employed (graph 3a), any combination of $\mathrm{pH}$ and $A C N$ ratio results in $R_{s} \geq 2$. The results showed in the graphs $3 \mathrm{~d}-3 \mathrm{f}$ confirm these observations, and show that high $\mathrm{pH}$ values produced higher values of $\mathrm{R}_{\mathrm{s}}$. Analyzing the scales of the graphs $3 \mathrm{~g}-3 \mathrm{i}$, the benefit of using high $\mathrm{pH}$ was confirmed, since the highest responses were found when $\mathrm{pH}$ was fixed at 4.7 (graph 3i). In general, the analysis of the nine response surfaces of Figure 3 shows that higher $R_{s}$ values were obtained when the following conditions were combined: low buffer concentration, high $\mathrm{pH}$, and high $\mathrm{ACN}$ ratio.

The response surfaces presented in Figure 4 were used to evaluate $\mathrm{A}_{\mathrm{s}}$. Analysis of graphs $4 \mathrm{a}-4 \mathrm{c}$ reveals that lower $A_{s}$ values were obtained when lower buffer concentrations were employed. According to graph $4 \mathrm{a}$, the combination of low ACN ratio and high $\mathrm{pH}$ value results in lower $\mathrm{A}_{\mathrm{s}}$ values. The analysis of graphs $4 \mathrm{~d}-4 \mathrm{f}$ confirms this observation. According to graph $4 \mathrm{~d}$, there was a tendency to obtain lower values of $A_{s}$ when the buffer concentration is $\leq 6 \mathrm{mmol} \mathrm{L}^{-1}$ and the $\mathrm{pH}$ is $\geq 4.4$. In the graphs $4 \mathrm{~g}-4 \mathrm{i}$, regardless of the $\mathrm{pH}$ employed, the combination between low $\mathrm{ACN}$ ratio and low buffer concentration results in low $\mathrm{A}_{\mathrm{s}}$ values.

The results of the response surface methodology are in agreement with the data obtained in the Pareto charts (data not shown). Peak height, baseline noise, N, peak width measured at $5 \%$ of the peak height, peak area, $t_{R}$ and $\mathrm{k}$ were also evaluated as responses. From the results of these analyses, showed in Table S3 (SI section), and from their respective response surface (data not shown), it was possible to identify the optimized conditions, considering the individual desirability of each parameter and the global desirability for the proposed method.

In order to verify if the defined optimal conditions result in optimum response values for the Gd-DTPA-BMA chromatographic peak, a new experiment was performed using mobile phase composed of $60 \% \mathrm{ACN}, \mathrm{NH}_{4} \mathrm{FA}$ at $5 \mathrm{mmol} \mathrm{L}^{-1}$ and mobile phase aqueous component $\mathrm{pH}$ of 4.5. Six determinations were performed in each experiment, being three determinations on a sample of Gd-DTPA-BMA at $0.3 \mu \mathrm{mol} \mathrm{mL} \mathrm{mL}^{-1}$ and three determinations on a sample of TTSL and LTSL spiked with Gd-DTPA-BMA at $0.3 \mu \mathrm{mol} \mathrm{mL} \mathrm{m}^{-1}$. Under these conditions, the signalto-noise ratio obtained was 9594265 . This result is in agreement with the highest signal-to-noise ratio found in the Box-Behnken planning experiments (experiment 6 , Table 3). The value of $R_{\mathrm{s}}$ obtained using the optimized conditions was equal to 3.2. This result was considered 
$\mathrm{pH} \times \mathrm{ACN}(\%)([$ buffer $]=5 \mathrm{mmol} \mathrm{L}-1)$

(a)

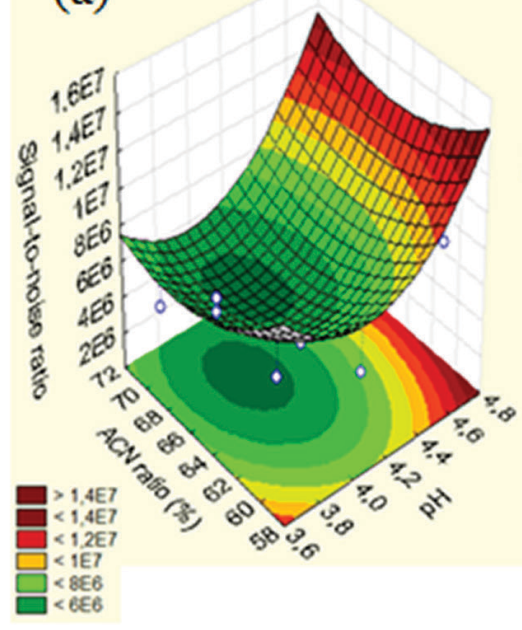

$\mathrm{pH} x[$ buffer] $(\mathrm{ACN}(\%)=60)$

(d)

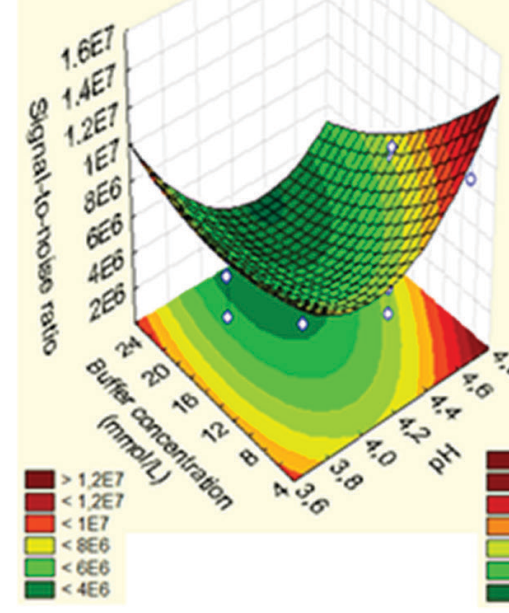

$\operatorname{ACN}(\%) \times[$ buffer $](\mathrm{pH}=3.7)$

(g)

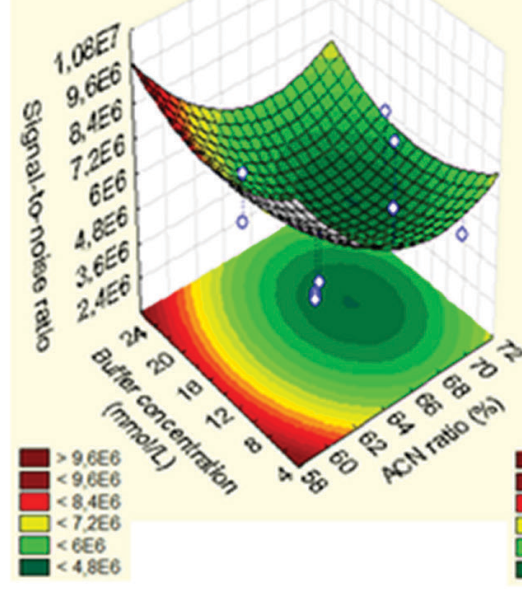

$\mathrm{pH} \times \mathrm{ACN}(\%)\left([\right.$ buffer] $\left.]=15 \mathrm{mmol} \mathrm{L}^{-1}\right) \mathrm{pH} \times \mathrm{ACN}(\%)\left([\right.$ buffer $\left.]=25 \mathrm{mmol} \mathrm{L}^{-1}\right)$ (b)

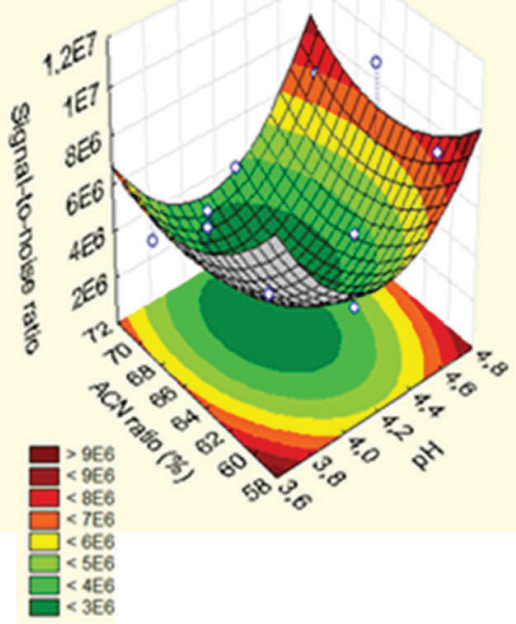

$\mathrm{pH} \times[$ buffer] $(\mathrm{ACN}(\%)=65)$

(e)

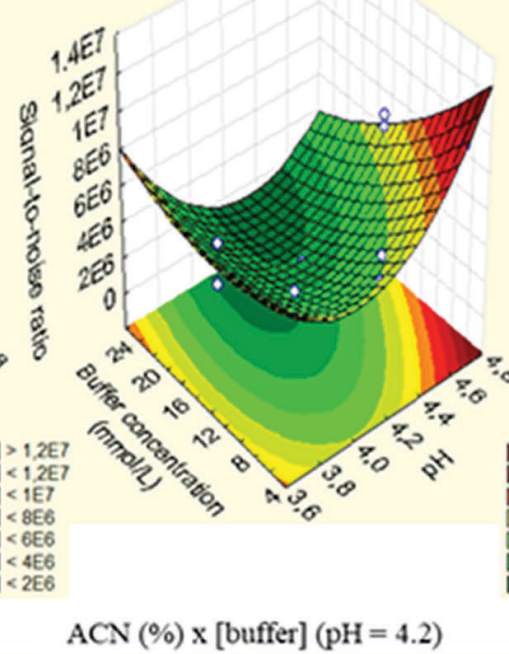

(h)

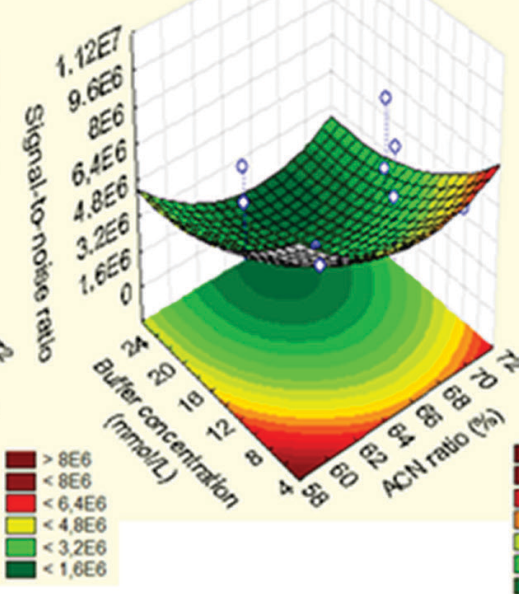

(c)

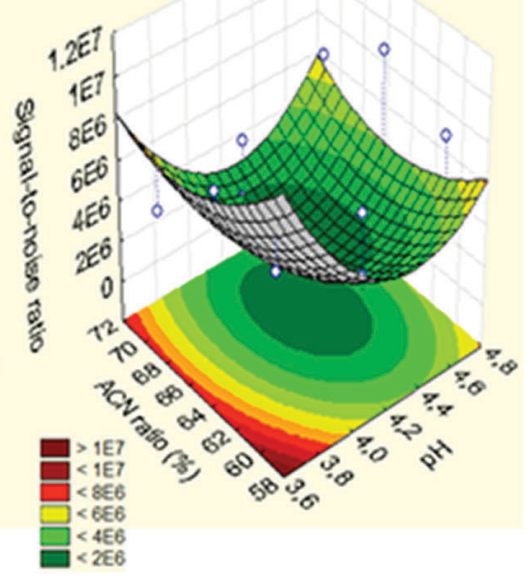

$\mathrm{pH} \times[$ buffer] $(\mathrm{ACN}(\%)=70)$

(f)

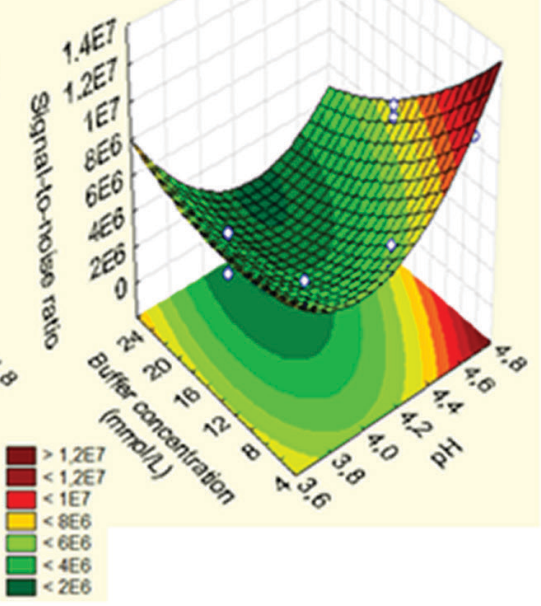

$\mathrm{ACN}(\%) \times[$ buffer] $(\mathrm{pH}=4.7)$

(i)

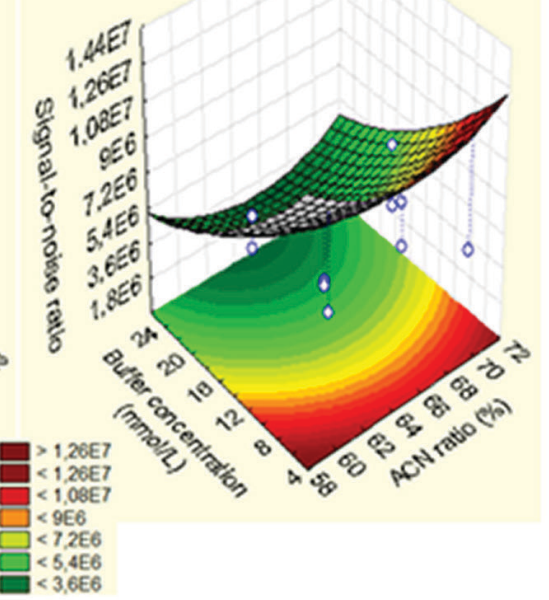

Figure 2. Response surfaces for evaluation of the dependent variable signal-to-noise ratio. 
$\mathrm{pH} \times \mathrm{ACN}(\%)$ ([buffer] $\left.=5 \mathrm{mmol} \mathrm{L}{ }^{-1}\right) \mathrm{pH} \times \mathrm{ACN}(\%)\left([\right.$ buffer $\left.]=15 \mathrm{mmol} \mathrm{L}^{-1}\right) \quad \mathrm{pH} \times \mathrm{ACN}(\%)\left([\right.$ buffer $\left.]=25 \mathrm{mmol} \mathrm{L}^{-1}\right)$

(a)

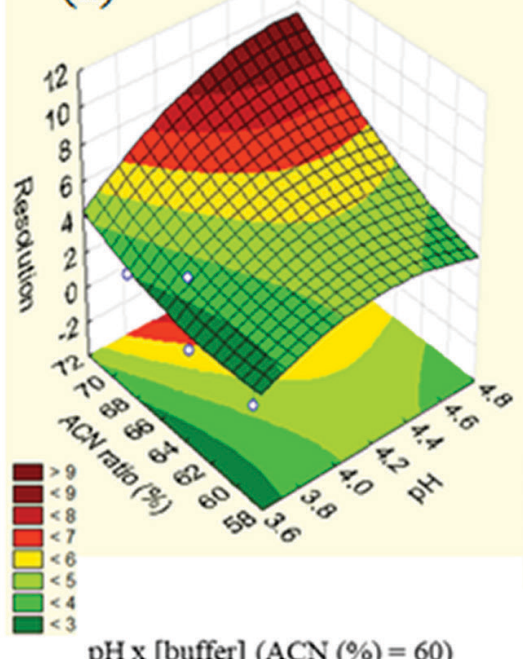

(d)

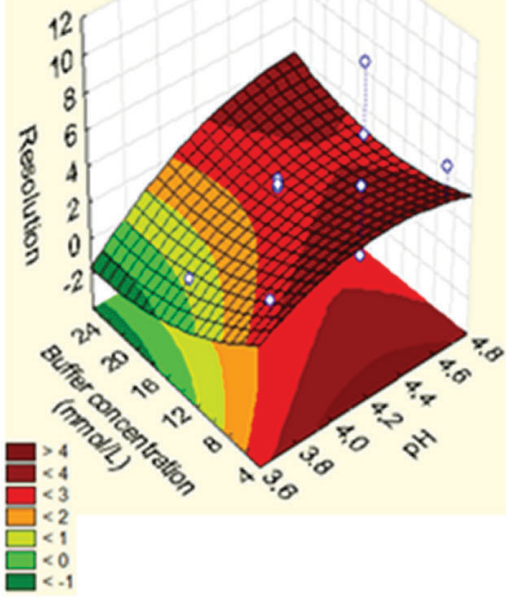

$\operatorname{ACN}(\%) \times[$ buffer $](\mathrm{pH}=3.7)$

(g)

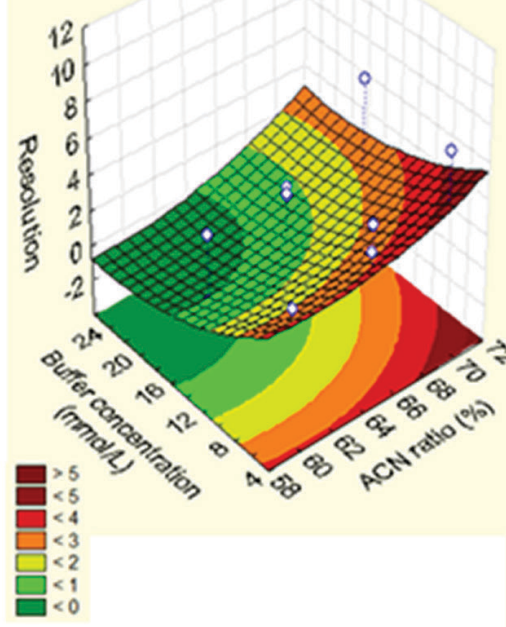

(b)

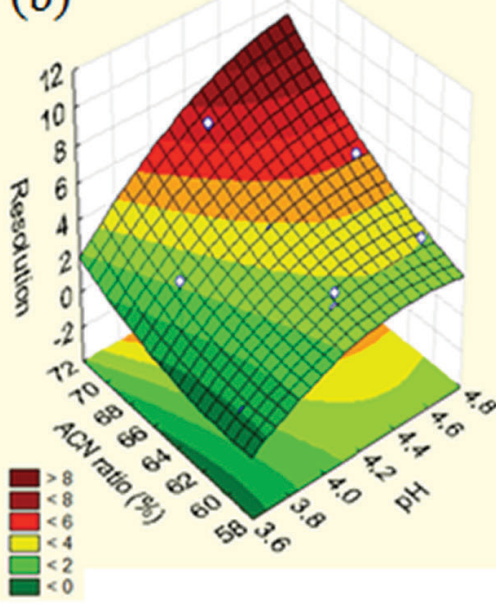

$\mathrm{pH} \times$ [buffer] $(\mathrm{ACN}(\%)=65)$

(e)

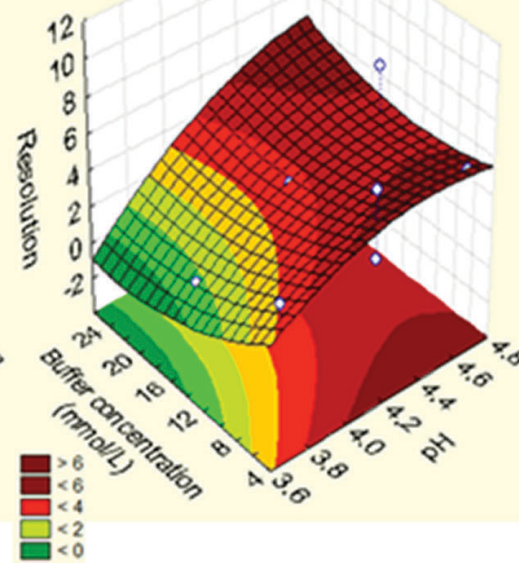

$\mathrm{ACN}(\%) \times$ [buffer] $(\mathrm{pH}=4.2)$

(h)

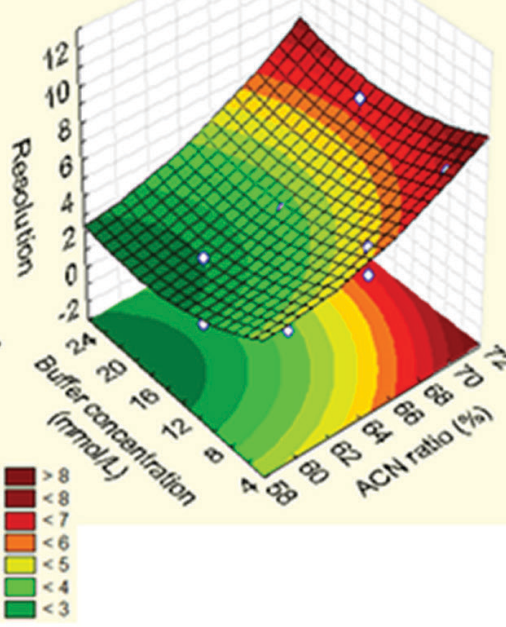

(c)

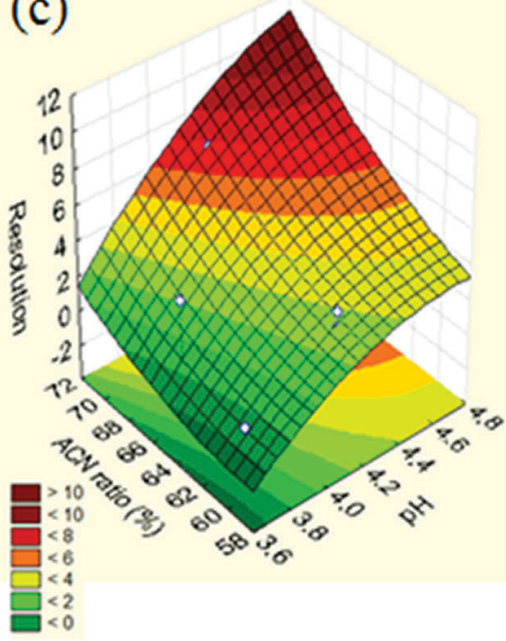

$\mathrm{pH} x$ [buffer] $(\mathrm{ACN}(\%)=70)$

(f)

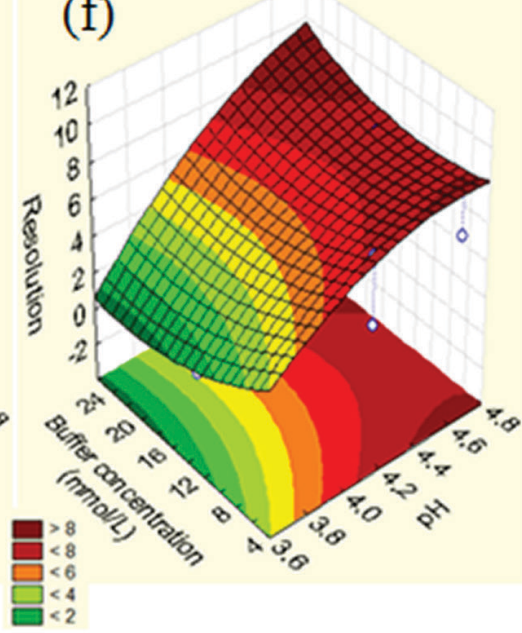

$\mathrm{ACN}(\%) \times[$ buffer] $(\mathrm{pH}=4.7)$

(i)

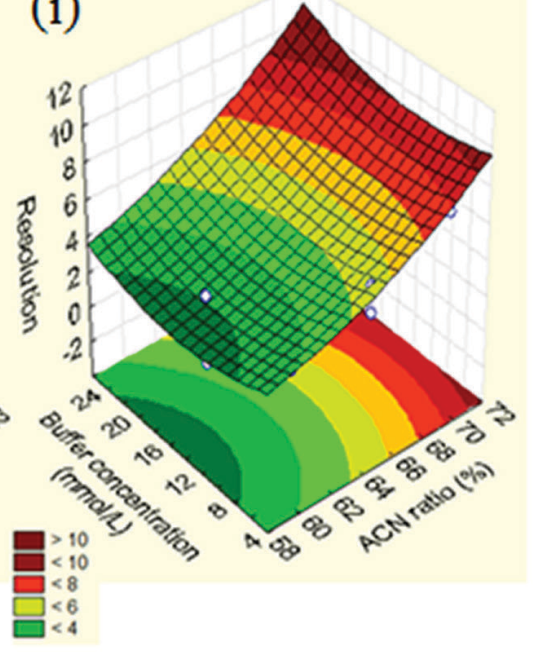

Figure 3. Response surfaces for evaluation of the dependent variable $\mathrm{R}_{\mathrm{s}}$. 
$\mathrm{pH} \times \mathrm{ACN}(\%)\left([\right.$ buffer] $\left.]=5 \mathrm{mmol} \mathrm{L}^{-1}\right) \mathrm{pH} \times \mathrm{ACN}(\%)\left([\right.$ buffer $\left.]=15 \mathrm{mmol} \mathrm{L}^{-1}\right) \quad \mathrm{pH} \times \mathrm{ACN}(\%)$ ([buffer $]=25 \mathrm{mmol} \mathrm{L}^{-1}$ )

(a)

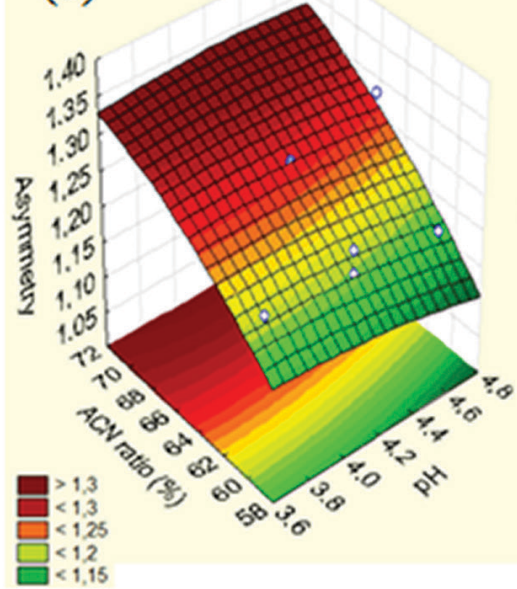

$\mathrm{pH} x$ [buffer] $(\mathrm{ACN}(\%)=60)$

(d)

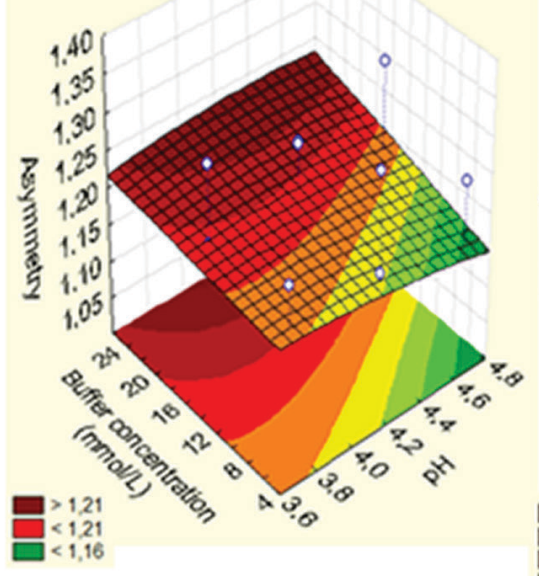

$\mathrm{ACN}(\%) \mathrm{x}$ [buffer] $(\mathrm{pH}=3.7)$

(g)

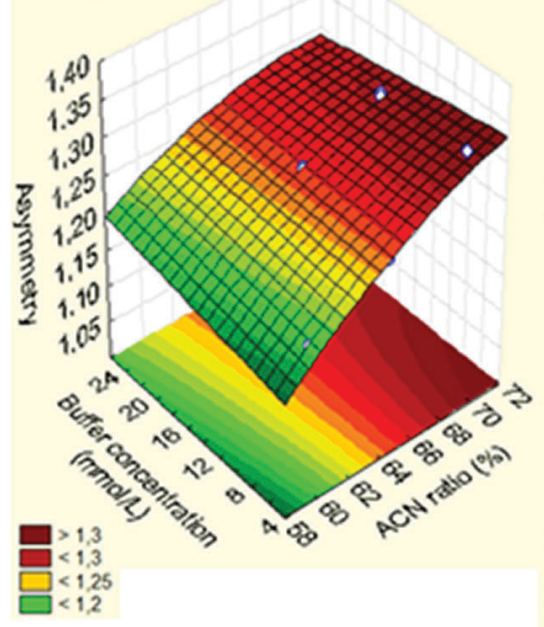

(b)

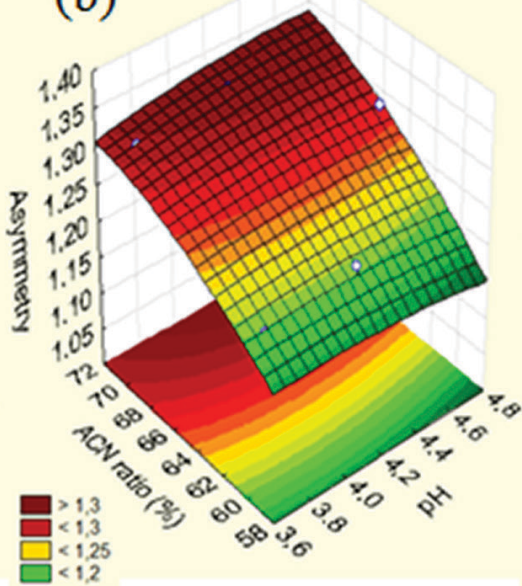

$\mathrm{pH} x$ [buffer] $(\mathrm{ACN}(\%)=65)$

(e)

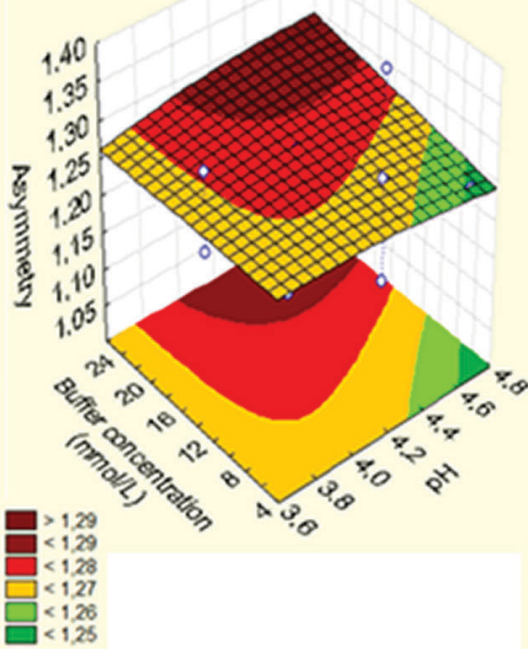

$\mathrm{ACN}(\%) \times$ [buffer] $(\mathrm{pH}=4.2)$

(h)

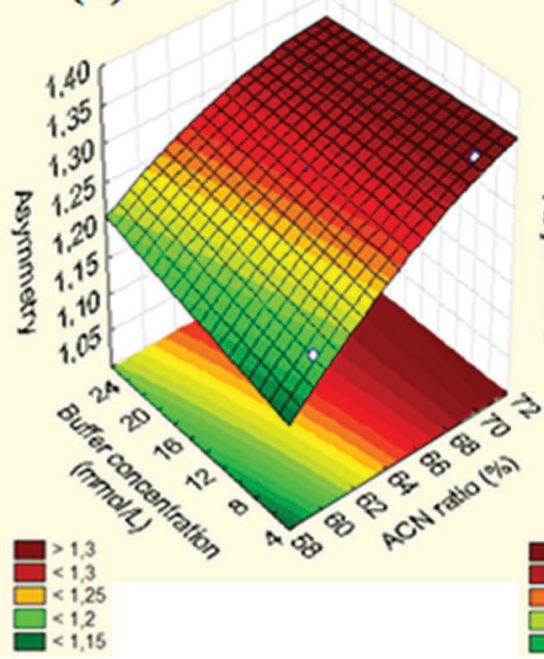

(c)

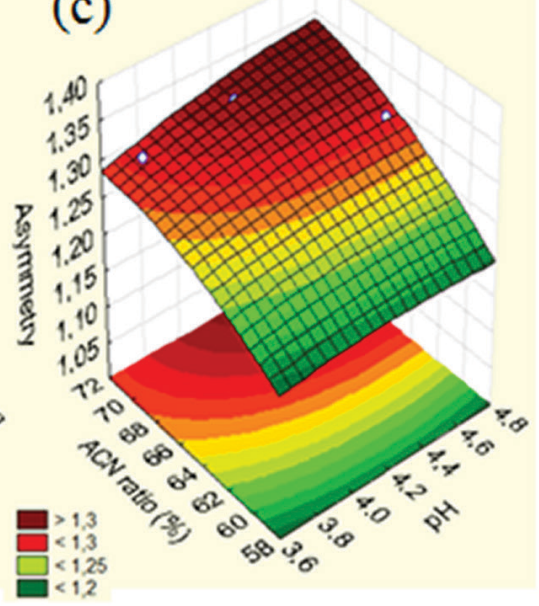

$\mathrm{pH} \times$ [buffer] $(\mathrm{ACN}(\%)=70)$

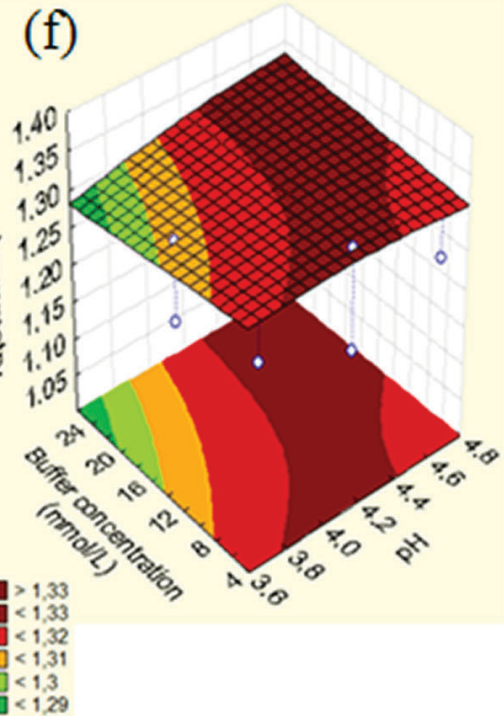

$\mathrm{ACN}(\%) x$ [buffer] $(\mathrm{pH}=4.7)$

(i)

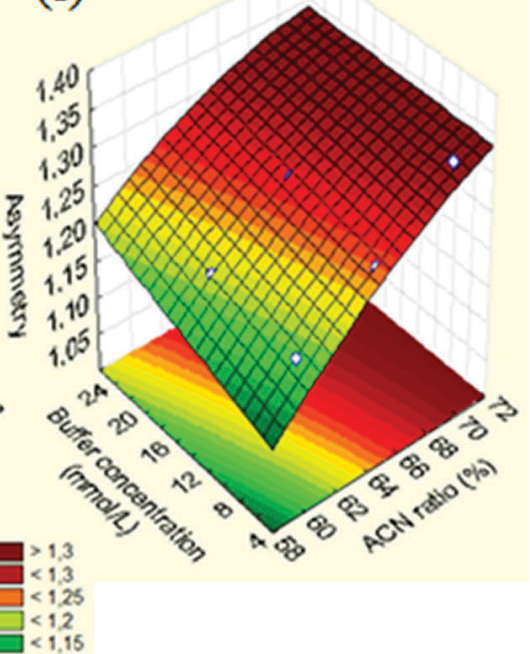

Figure 4. Response surfaces for evaluation of the dependent variable $A_{s}$. 
adequate, since it is higher than the recommended value $\left(R_{s} \geq 2\right)$ to obtain a satisfactory separation between the drug and the possible interferences. ${ }^{49-51}$ The $\mathrm{A}_{\mathrm{s}}$ obtained after optimization of the chromatographic parameters was 1.11. This value corresponds to the best response obtained for this parameter, considering all the experiments performed. In addition, it complies with the limits established by the FDA. ${ }^{54}$

The Van Deemter curve obtained to optimize the mobile phase flow-rate is shown in Figure 5. The maximum efficiency observed ( $\mathrm{H}$ around $18 \mu \mathrm{m}$ ), using the optimized chromatographic conditions, was observed in $\mathrm{U}_{0}$ close to $0.16 \mathrm{~mm} \mathrm{~s}^{-1}$, corresponding to a flow of $0.1 \mathrm{~mL} \mathrm{~min}^{-1}$. This flow-rate is not feasible to be used in the routine analyses, since it results in a very long $t_{R}$ for Gd-DTPA-BMA $\left(t_{R}=44.15 \mathrm{~min}\right)$. Thus, the optimization of the mobile phase flow-rate was performed evaluating the parameters $t_{R}$, N, peak height and $R_{s}$ (Table S4, SI section). Based on the results obtained, the flow-rate of $0.6 \mathrm{~mL} \mathrm{~min}{ }^{-1}$ was selected for use in the developed method. When compared to the flow-rate of $1.0 \mathrm{~mL} \mathrm{~min}{ }^{-1}$, it resulted in a higher Gd-DTPA-BMA $t_{R}\left(t_{R}=7.1 \mathrm{~min}\right)$. However, this flow rate allowed increasing $29 \%$ efficiency (directly related to $\mathrm{N}$ ) and $12 \%$ of detectability and $\mathrm{R}_{\mathrm{s}}$ of the proposed method.

\section{Method validation}

Chromatograms of the formulations, without Gd-DTPA-BMA (TTSL/LTSL), isopropyl alcohol, fetal bovine serum, and mobile phase (Figure 6), showed no interfering peaks at the retention time of Gd-DTPA-BMA (b)
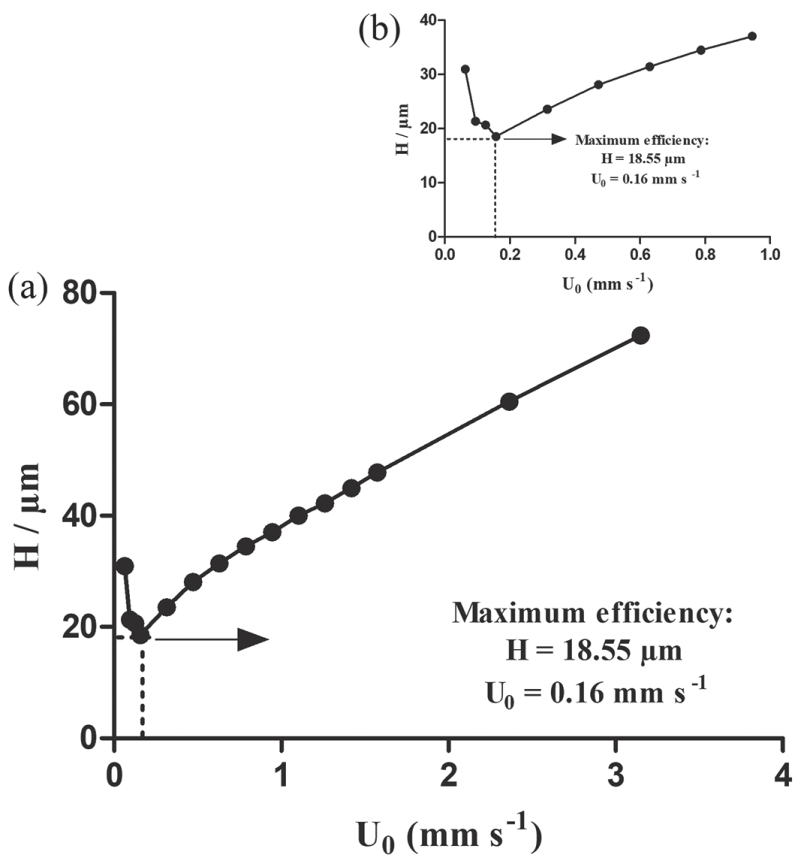

Figure 5. Van Deemter curve using the optimized chromatographic conditions of the developed method.

$\left(t_{R}=7.1 \mathrm{~min}\right)$, demonstrating the selectivity of the method. The resolution obtained between Gd-DTPA-BMA and TTSL/LTSL was adequate $\left(R_{s}=3.6\right)$. In addition, the purity of the Gd-DTPA-BMA peak, calculated by DAD, was equal to $100 \%$ in all determinations. Although the aim of this study is to determine Gd-DTPA-BMA in liposomes, the selectivity in a biological sample (fetal bovine serum) was evaluated to demonstrate that, if necessary, the developed method can be applied in more complex matrices.

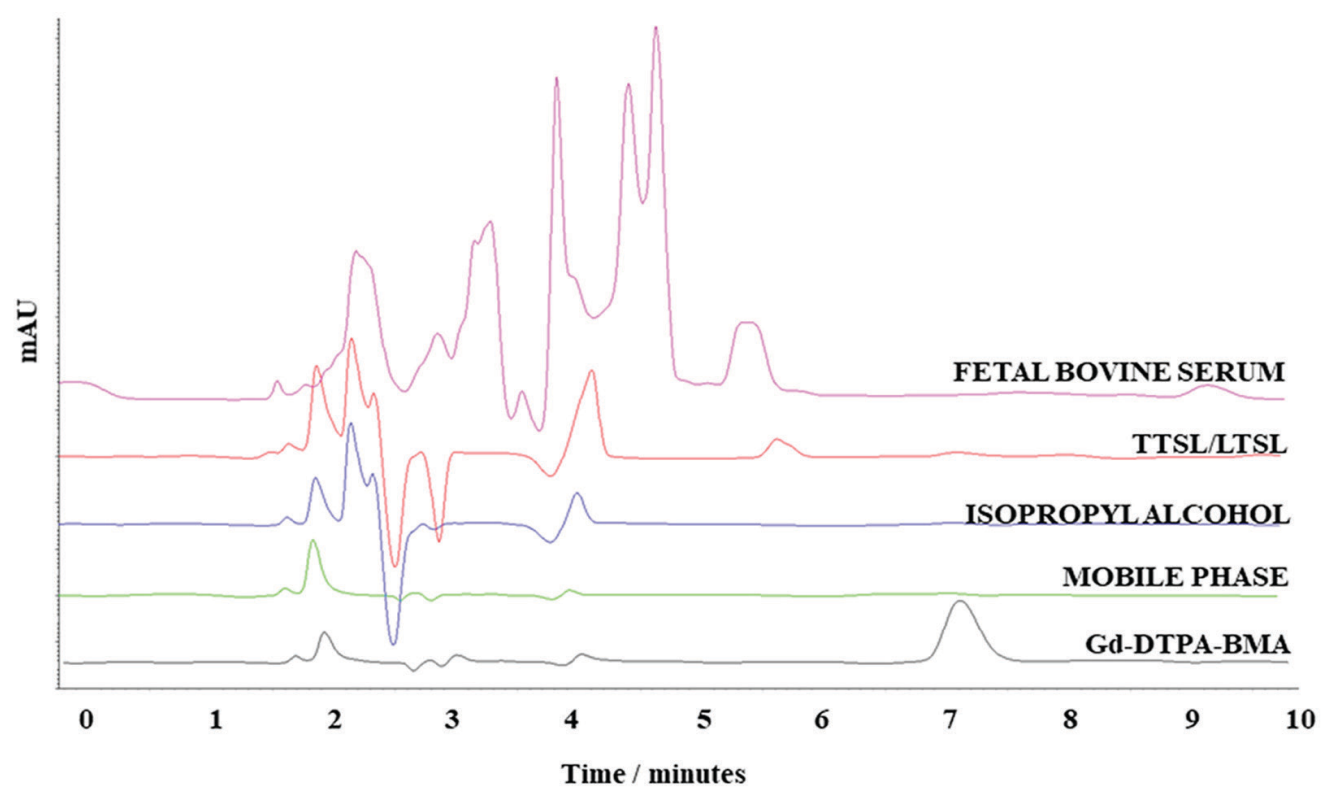

Figure 6. Representative chromatograms from the selectivity study: fetal bovine serum, TTSL/LTSL, isopropyl alcohol, mobile phase, and Gd-DTPA-BMA $\left(40 \mathrm{nmol} \mathrm{mL} \mathrm{m}^{-1}\right)$. 
The method showed to be linear in the range between 40 and $120 \mathrm{nmol} \mathrm{L}^{-1}$. The equation of the calibration curve obtained was $y=803100 x+964900$. The $\mathrm{r}$ and $\mathrm{r}^{2}$ obtained were satisfactory $(>0.999) .{ }^{30}$ There was no significant difference between the slopes of the three calibration curves obtained $(p<0.05)$.

The determination of LOD and LOQ of Gd-DTPA-BMA was performed initially by means of the evaluation of the signal-to-noise ratio in order to include LOQ as the lowest concentration level of the linear range of the analytical curve. After linearity evaluation, the theoretical values of LOD and LOQ, calculated based on the parameters of linear

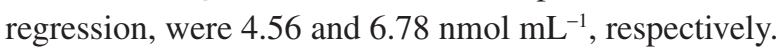

From our knowledge, no studies dealing with Gd-DTPA-BMA determination by HILIC in liposomes have been reported in the literature until the present date. Moreover, no studies of determination of Gd-DTPA-BMA by HILIC with DAD detection were found. In contrast, some studies of determination of Gd-DTPA-BMA by HILIC using MS detection have already been described..$^{20,25-29}$ Despite the indisputable detectability provided by MS, the high cost of analysis and instrumentation justifies the development of simpler and less costly method. In a previous study by our research group, ${ }^{2}$ an analytical method for the determination of Gd-DTPA-BMA by RP-LC/DAD was developed and validated. It showed to be linear in the range between 100 and $500 \mathrm{nmol} \mathrm{mL}^{-1}$. At the present HILIC method, lower concentrations can be included in the analytical curve (40 to $120 \mathrm{nmol} \mathrm{mL}^{-1}$ ). In addition, comparing the LOD and LOQ obtained in the two studies, one can conclude that the HILIC method showed detectability five-fold higher using the same type of detector (DAD).

The developed method demonstrated adequate precision (Table 4). The obtained RSD values for intra-day and inter-day precisions were satisfactory and in agreement with the specification established by RE $899,{ }^{30}$ which recommends $\mathrm{RSD} \leq 5 \%$.

The accuracy of the developed method was demonstrated (Table 4). The result for mean recovery was $98.61 \%$ for TTSL/LTSL formulations. In addition, the value of RSD between measurements did not exceed $5 \%$.

The results of robustness were presented in Table 5 . According to the obtained data, the method showed to be robust for all the evaluated parameters, since the effects of each variable were lower than the respective largest effect calculated.

\section{Determination of Gd-DTPA-BMA entrapment and drug encapsulation percentage}

The developed method was used to evaluate the Gd-DTPA-BMA content in TTSL-Gd and LTSL-Gd formulations. Three batches of each formulation were prepared for this analysis. The chromatograms were obtained by using the mobile phase as sample diluent. The values obtained were $26.41 \pm 4.04 \mu \mathrm{mol} \mathrm{mL} \mathrm{mL}^{-1}$ $(10.56 \pm 1.62 \%)$ and $22.95 \pm 3.07 \mu \mathrm{mol} \mathrm{mL}^{-1}(9.18 \pm 1.23 \%)$ for TTSL-Gd and LTSL-Gd, respectively. The amount of Gd-DTPA-BMA entrapment found, in terms of $\mu \mathrm{mol} \mathrm{mL}^{-1}$, was similar to the concentration determined for $\mathrm{pH}$-sensitive and stealth $\mathrm{pH}$-sensitive liposomes developed in a previously study from our research group. ${ }^{3}$ The encapsulation percentages found are in agreement with values obtained in thermosensitive formulations containing Gd-DTPA-BMA, developed for use in magnetic resonance. ${ }^{7}$ The drug entrapment is an essential physicochemical parameter in the development of a new drug delivery system. The results of this analysis confirms the applicability of the HILIC method to the development and characterization of liposomal formulations containing Gd-DTPA-BMA.

Table 4. Intra-day precision, inter-day precision, and values of Gd-DTPA-BMA recovery obtained with HILIC method

\begin{tabular}{|c|c|c|c|c|c|c|c|c|c|}
\hline \multirow{3}{*}{$\begin{array}{l}\text { Linear } \\
\text { range } / \%\end{array}$} & \multicolumn{3}{|c|}{ 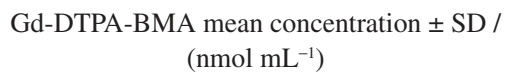 } & \multicolumn{3}{|c|}{$\mathrm{RSD} / \%$} & \multicolumn{3}{|c|}{ Accuracy result } \\
\hline & \multicolumn{2}{|c|}{ Intra-day $^{\mathrm{a}}$} & \multirow{2}{*}{ Inter-day ${ }^{b}$} & \multicolumn{2}{|c|}{ Intra-day $^{\mathrm{a}}$} & \multirow{2}{*}{ Inter-day ${ }^{b}$} & \multirow{2}{*}{$\begin{array}{l}\text { Gd-DTPA-BMA } \\
\text { amount added / } \\
\left(\mathrm{nmol} \mathrm{mL} \mathrm{mL}^{-1}\right)\end{array}$} & \multirow{2}{*}{$\begin{array}{l}\text { Gd-DTPA-BMA mean } \\
\text { concentration } \pm \text { SD / } \\
\left(\mathrm{nmol} \mathrm{mL}^{-1}\right)\end{array}$} & \multirow{2}{*}{$\begin{array}{c}\text { Mean recovery }{ }^{\mathrm{a}} \pm \\
\mathrm{SD} / \%\end{array}$} \\
\hline & Day 1 & Day 2 & & Day 1 & Day 2 & & & & \\
\hline 50 & $39.59 \pm 0.41$ & $38.82 \pm 0.52$ & $39.20 \pm 0.59$ & 1.05 & 1.33 & 1.51 & 40 & $38.93 \pm 0.37$ & $97.32 \pm 0.93$ \\
\hline 100 & $79.80 \pm 0.86$ & $79.13 \pm 0.23$ & $79.47 \pm 0.67$ & 1.08 & 0.29 & 0.85 & 80 & $79.41 \pm 0.31$ & $99.26 \pm 0.38$ \\
\hline 150 & $119.50 \pm 0.60$ & $119.49 \pm 0.94$ & $119.50 \pm 0.71$ & 0.50 & 0.79 & 0.59 & 120 & $119.10 \pm 1.97$ & $99.25 \pm 1.65$ \\
\hline Mean $^{\mathrm{c}}$ & & & & & & & & & $98.61 \pm 1.37$ \\
\hline $\mathrm{RSD}^{\mathrm{c}} / \%$ & & & & & & & & & 1.38 \\
\hline
\end{tabular}

${ }^{\mathrm{a}}$ Mean of three determinations; ${ }^{\mathrm{b}}$ mean of six determinations; ${ }^{\mathrm{c}}$ mean of nine determinations. Gd-DTPA-BMA: gadodiamide; SD: standard deviation; RSD: relative standard deviation. 
Table 5. Evaluation of the effect of the variables, in terms of content, $\mathrm{R}_{\mathrm{s}}$ and $\mathrm{A}_{\mathrm{s}}$ in the determination of Gd-DTPA-BMA using the developed method

\begin{tabular}{|c|c|c|c|}
\hline Variable & Content $^{\mathrm{a}} / \%$ & $\mathrm{R}_{\mathrm{s}}{ }^{\mathrm{a}}$ & $\mathrm{A}_{\mathrm{s}}{ }^{\mathrm{a}}$ \\
\hline $\begin{array}{l}\mathrm{ACN} \text { ratio in the mobile phase } \\
(\mathrm{A}=60 \% ; \mathrm{a}=63 \%)\end{array}$ & $101.37-100.87=0.50$ & $3.21-4.57=-1.36$ & $1.32-1.28=0.04$ \\
\hline $\begin{array}{l}\text { The aqueous phase } \mathrm{pH} \text { of the mobile phase } \\
(\mathrm{B}=4.5 ; \mathrm{b}=4.7)\end{array}$ & $100.61-101.64=-1.03$ & $4.06-3.72=0.34$ & $1.26-1.34=-0.08$ \\
\hline $\begin{array}{l}\text { Buffer concentration } \\
\left(\mathrm{C}=5 \mathrm{mmol} \mathrm{L}^{-1} ; \mathrm{c}=5.5 \mathrm{mmol} \mathrm{L}^{-1}\right)\end{array}$ & $101.46-100.78=0.68$ & $3.56-4.22=-0.66$ & $1.29-1.30=-0.01$ \\
\hline $\begin{array}{l}\text { Column temperature } \\
\left(\mathrm{D}=30^{\circ} \mathrm{C} ; \mathrm{d}=33^{\circ} \mathrm{C}\right)\end{array}$ & $101.35-100.90=0.45$ & $3.80-3.98=-0.18$ & $1.29-1.31=-0.02$ \\
\hline $\begin{array}{l}\text { Flow } \\
\left(\mathrm{E}=0.6 \mathrm{~mL} \mathrm{~min}^{-1} ; \mathrm{e}=0.7 \mathrm{~mL} \mathrm{~min}^{-1}\right)\end{array}$ & $101.16-101.09=0.07$ & $4.37-3.41=0.96$ & $1.28-1.31=-0.03$ \\
\hline $\begin{array}{l}\text { ACN brand } \\
(\mathrm{F}=\text { Tedia; } \mathrm{f}=\text { J.T.Baker })\end{array}$ & $101.54-100.70=0.84$ & $3.83-3.95=-0.12$ & $1.25-1.35=-0.10$ \\
\hline $\begin{array}{l}\text { Buffer brand } \\
(\mathrm{G}=\text { Vetec; } \mathrm{g}=\text { Spectrum })\end{array}$ & $101.26-100.98=0.28$ & $4.05-3.73=0.32$ & $1.26-1.34=-0.08$ \\
\hline Largest effect ${ }^{\mathrm{b}}$ & 1.24 & 36.06 & 8.97 \\
\hline
\end{tabular}

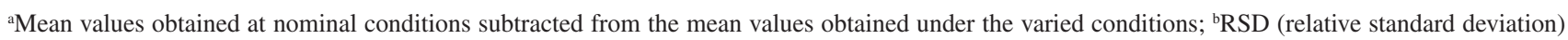
between the values obtained in the 8 experiments multiplied by root of 2 . $\mathrm{R}_{\mathrm{s}}$ : resolution; $\mathrm{A}_{\mathrm{s}}$ : asymmetry.

\section{Conclusions}

In the present study, an analytical method for the determination of Gd-DTPA-BMA in liposomes by HILIC was developed, using chemometric tools, validated and applied for determination of Gd-DTPA-BMA entrapment and drug encapsulation percentage in liposomes. The developed method showed to be simple, fast and selective. In addition, it presented adequate detectability, proving to be suitable to determine Gd-DTPA-BMA in the development of liposomal formulations. Although this method has been used to determine a single analyte, it presented selectivity to be used in more complex samples, as demonstrated for fetal bovine serum sample. In this context, the use of Box-Behnken factorial design and response surface methodology was effective for method development. This approach allowed evaluating the interaction between the parameters and obtaining results that probable would not be observed in a univariate analysis. Although some methods for determining Gd-DTPA-BMA in different matrices by HILIC have been described, none has been applied for analysis of liposomes. In addition, from our knowledge, until the present date, no quantification study of Gd-DTPA-BMA by a rational chemometric-assisted HILIC has been found in the literature.

\section{Supplementary Information}

Supplementary information is available free of charge at http://jbcs.sbq.org.br as PDF file.

\section{Acknowledgments}

The authors would like to thank CNPq (Conselho Nacional de Desenvolvimento Científico e Tecnológico), FAPEMIG (Fundação de Amparo à Pesquisa do Estado de Minas Gerais) and CAPES (Coordenação de Aperfeiçoamento de Pessoal de Nível Superior) for their financial support.

\section{References}

1. Telgmann, L.; Sperling, M.; Karst, U.; Anal. Chim. Acta 2013, $764,1$.

2. Maia, A. L. C.; Silva, T. D.; Oliveira, C. N. P.; Silveira, J. N.; Ramaldes, G. A.; Anal. Methods 2015, 7, 8315.

3. Maia, A. L. C.; Fernandes, C.; Oliveira, C. N. P.; Teixeira, C. S.; Oliveira, M. S.; Soares, D. C. F.; Ramaldes, G. A.; Curr. Drug Delivery 2017, 14, 566.

4. EMA/625317/2017: EMA's Final Opinion Confirms Restrictions on Use of Linear Gadolinium Agents in Body Scans, European Medicines Agency (EMA): London, UK, 2017.

5. Ghaghada, K.; Hawley, C.; Kawaji, K.; Annapragada, A.; Mukundan Jr., S.; Acad. Radiol. 2008, 15, 1259.

6. Grahn, A. Y.; Bankiewicz, K. S.; Dugich-djordjevic, M.; Bringas, J. R.; Hadaczek, P.; Johnson, G. A.; Eastman, S.; Luz, M.; J. Neuro-Oncol. 2009, 95, 185.

7. Hossann, M.; Wang, T.; Wiggenhorn, M.; Schmidt, R.; Zengerle, A.; Winter, G.; Eibl, H.; Peller, M.; Reiser, M.; Issels, R. D.; Lindner, L. H.; J. Controlled Release 2010, 147, 436.

8. Soares, D. C. F.; Oliveira, M. C.; Barros, A. L. B.; Cardoso, V. N.; Ramaldes, G. A.; Eur. J. Pharm. Sci. 2011, 43, 290. 
9. Soares, D. C. F.; Oliveira, M. C.; Santos, R. G.; Andrade, M. S.; Vilela, J. M. C.; Cardoso, V. N.; Ramaldes, G. A.; Eur. J. Pharm. Sci. 2011, 42, 462.

10. Soares, D. C. F.; Cardoso, V. N.; Barros, A. L. B.; Souza, C. M.; Cassali, G. D.; Oliveira, M. C.; Ramaldes, G. A.; Eur. J. Pharm. Sci. 2012, 45, 58.

11. Dewi, N.; Yanagie, H.; Zhu, H.; Demachi, K.; Shinohara, A.; Yokoyama, K.; Sekino, M.; Sakurai, Y.; Morishita, Y.; Iyomoto, N.; Nagasaki, T.; Horiguchi, Y.; Nagasaki, Y.; Nakajima, J.; Ono, M.; Kakimi, K.; Takahashi, H.; Biomed. Pharmacother. 2013, 67,451 .

12. Soares, D. C. F.; Barros, A. L. B.; Santos, R. G. S.; Sousa, E. M. B.; Ramaldes, G. A.; J. Radioanal. Nucl. Chem. 2013, 295, 63.

13. Issels, R.; Kampmann, E.; Kanaar, R.; Lindner, L. H.; Int. J. Hyperthermia 2016, 32, 89.

14. Behra-miellet, J.; Briand, G.; Kouach, M.; Gressier, B.; Cazin, M.; Cazin, J. C.; Biomed. Chromatogr. 1998, 12, 21.

15. Frenzel, T.; Lensfeld, P.; Schirmer, H.; Hütter, J.; Weinmann, H. J.; Invest. Radiol. 2008, 43, 817.

16. Kahakachchi, C. L.; Moore, D. A.; J. Anal. At. Spectrom. 2009 , $24,1389$.

17. Kindberg, G. M.; Uran, S.; Friisk, G.; Martinsen, I.; Skotland, T.; Eur. Radiol. 2010, 20, 1636.

18. United States Pharmacopeia (USP); USP 34-NF 29; The United States Pharmacopeial Convention: Rockville, 2011, p. 29342937.

19. Normann, P. T.; Hals, P. A.; Eur. J. Drug Metab. Pharmacokinet. 1995, 20, 307.

20. Raju, C. S. K.; Cossmer, A.; Scharf, H.; Panne, U.; Lück, D.; J. Anal. At. Spectrom. 2010, 25, 55.

21. Greco, G.; Letzel, T.; J. Chromatogr. Sci. 2013, 51, 684.

22. Buszewski, B.; Noga, S.; Anal. Bioanal. Chem. 2012, 402, 231.

23. Acevska, J.; Stefkov, G.; Petkovska, R.; Kulevanova, S.; Dimitrovska, A.; Anal. Bioanal. Chem. 2012, 403, 1117.

24. Sahu, P. K.; Patro, C. S.; J. Liq. Chromatogr. Relat. Technol. 2014, 37, 2444.

25. Künnemeyer, J.; Terborg, L.; Nowak, S.; Scheffer, A.; Telgmann, L.; Tokmak, F.; Günsel, A.; Wiesmüller, G.; Reichelt, S.; Karst, U.; Anal. Chem. 2008, 80, 8163.

26. Künnemeyer, J.; Terborg, L.; Meermann, B.; Brauckmann, C.; Möller, I.; Scheffer, A.; Karst, U.; Environ. Sci. Technol. 2009, 43, 2884.

27. Telgmann, L.; Wehe, C. A.; Birka, M.; Künnemeyer, J.; Nowak, S.; Sperling, M.; Karst, U.; Environ. Sci. Technol. 2012, 46, 11929.

28. Lindner, U.; Lingott, J.; Richter, S.; Jakubowski, N.; Panne, U.; Anal. Bioanal. Chem. 2013, 405, 1865.

29. Lindner, U.; Lingott, J.; Richter, S.; Jiang, W.; Jakubowski, N.; Panne, U.; Anal. Bioanal. Chem. 2015, 407, 2415.
30. Ministério da Saúde, Agência Nacional de Vigilância Sanitária; Resolução RE No. 899, de 29 de maio de 2003, Guia de Validação de Métodos Analíticos e Bioanalíticos, Diário Oficial da União, Brasília, 2003.

31. International Conference on Harmonisation of Technical Requirements for Registration of Pharmaceuticals for Human Use (ICH); Guideline Q2(R1) - Validation of Analytical Procedures: Text and Methodology; ICH: Geneva, 2005.

32. Szoka Jr., F.; Papahadjopoulos, D.; Proc. Natl. Acad. Sci. U. S. A. 1978, 75, 4194.

33. Li, L.; Hagen, T. L. M. T.; Hossann, M.; Süss, R.; Rhoon, G. C. V.; Eggermont, A. M. M.; Haemmerich, D.; Koning, G. A.; J. Controlled Release 2013, 168, 142.

34. Bezerra, M. A.; Santelli, R. E.; Oliveira, E. P.; Villar, L. S.; Escaleira, L. A.; Talanta 2008, 76, 965.

35. Statistica 7.0, StatSoft@, Tulsa, USA, 2004.

36. Van Deemter, J. J.; Zuiderweg, F. J.; Klinkenberg, A.; Chem. Eng. Sci. 1956, 5, 271.

37. GraphPad Prism 5.0, GraphPad Software Inc., San Diego, USA, 2007.

38. Ribeiro, F. A. L.; Ferreira, M. M. C.; Morano, S. C.; Silva, L. R.; Schneider, R. P.; Quim. Nova 2008, 31, 164.

39. Youden, W. J.; Steiner, E. H.; Statistical Manual of AOAC; Association of Official Analytical Chemistry (AOAC): Washington, USA, 1975.

40. Cass, Q. B.; Cassiano, N.; Cromatografia Líquida: Novas Tendências e Aplicações, $1^{\text {a }}$ ed.; Elsevier: Rio de Janeiro, 2015.

41. Control No. 169935: Product Monograph: Omniscan ${ }^{T M}$ (Gadodiamide Injection USP), GE Healthcare: Ontario, Canada, 2013.

42. Merbach A.; Helm, L.; Tóth, E.; The Chemistry of Contrast Agents in Medical Magnetic Resonance Imaging, $2^{\text {nd }}$ ed.; John Wiley \& Sons: United Kingdom, 2013.

43. Chirita, R. I.; West, C.; Finaru, A. L.; Elfakir, C.; J. Chromatogr. A 2010, 1217, 3091.

44. Hemström, P.; Irgum, K.; J. Sep. Sci. 2006, 29, 1784.

45. Vora, M. M.; Wukovnig, S.; Finn, R. D.; Emran, A. M.; Boothe, T. E.; Kothari, P. J.; J. Chromatogr. 1986, 369, 187.

46. Hvattum, E.; Normann, P. T.; Jamieson, G. C.; Lai, J. J.; Skotland, T.; J. Pharm. Biomed. Anal. 1995, 13, 927.

47. Guo, Y.; Gaiki, S.; J. Chromatogr. A 2011, 1218, 5920.

48. Karatapanis, A. E.; Fiamegos, Y. C.; Stalikas, C. D.; J. Chromatogr. A 2011, 1218, 2871.

49. United States Food and Drug Administration; Guidance for Industry, Analytical Procedures and Methods Validation, Rockville, USA, 2000.

50. Ribani, M.; Bottoli, C. B. G.; Collins, C. H.; Jardim, I. C. S. F.; Melo, L. F. C.; Quim. Nova 2004, 27, 771.

51. Snyder, L. R.; Kirkland, J. J.; Geajch, J. L.; Practical HPLC Method Development, $2^{\text {nd }}$ ed.; John Wiley \& Sons: New York, 2007. 
52. Thermo Scientific; HILIC Separations Technical Guide. A Practical Guide to HILIC Mechanisms, Method Development and Troubleshooting, Thermo Scientific, 2014.

53. Teófilo, R. F.; Ferreira, M. M. C.; Quim. Nova 2006, 29, 338.
54. United States Food and Drug Administration; Reviewer Guidance Validation of Chromatographic Methods, Center for Drug Evaluation and Research: Rockville, USA, 1994.

Submitted: January 22, 2018

Published online: June 22, 2018 